ARTÍCULO

\title{
SANTA ANNA COMO FAETÓN EN UNA CARICATURA DE EL GALLO PITAGÓRICO (1845)
}

\section{SANTA ANNA AS PHAETHON IN A CARICATURE FROM EL GALLO PITAGÓRICO (1845)}

\author{
Helia Emma Bonilla Reyna \\ Instituto Nacional de Antropología e Historia \\ Dirección de Estudios Históricos \\ helia_bonilla@hotmail.com
}

Resumen

En este artículo se analiza una significativa caricatura publicada en El Gallo Pitagórico, libro escrito e impreso respectivamente por Juan Bautista Morales e Ignacio Cumplido en 1845, con el fin de impulsar los intereses del grupo liberal moderado, al cual ambos pertenecían. Puesta a la luz del trasfondo político, la imagen refleja las tensiones que vivieron al enfrentar a Santa Anna y sus seguidores en un entorno de incertidumbre política.

Palabras clave: caricatura, política, siglo xıx, liberales moderados, movimiento decembrista, El Gallo Pitagórico, Antonio López de Santa Anna.

\begin{abstract}
This article analyzes a significant caricature published in El Gallo Pitagórico, a book written and printed respectively by Juan Bautista Morales and Ignacio Cumplido in 1845. Viewed from a political context, the caricature promotes the interests of the moderate liberal group to which both belonged and reflects the tensions they experienced when confronting Santa Anna and his advocates in an environment of political uncertainty.
\end{abstract}

Keywords: caricature, politics, nineteenth-century, moderate liberals, movimiento decembrista, El Gallo Pitagórico, Antonio López de Santa Anna.

Información del artículo

Recibido: 5 de septiembre de 2018.

Aceptado: 2 de febrero de 2019.

DOI: 10.22201/iih.24485004e.2018.56.67086 
Este artículo se aboca a desentrañar la significación de la imagen litográfica Que Jupiter con sus rayos los arrojara de cabeza al lago de Texcoco, que junto con varias otras, y algunos grabados, ilustró la primera edición de El Gallo Pitagórico, libro bien conocido dentro de la historiografía de la gráfica mexicana decimonónica, el cual, con un sesgo literario y costumbrista, tuvo en realidad una función denostadora y un claro objetivo político. ${ }^{1}$ Con el fin de entender más precisamente cuál fue este objetivo, y cuáles los hechos específicos aludidos en la imagen que se examinará, conviene observar desde dónde se enunciaron, contra quién, en qué momento o contexto histórico, y a partir de qué estrategias, además de la elusión. En última instancia, el análisis permitirá observar cuál fue la actuación de algunas de las figuras protagónicas de la escena política de la época, así como las tensiones, las incongruencias y los reposicionamientos entre el santannismo y el grupo de los liberales moderados, que en estos años tuvieron una actuación destacada en la esfera política mexicana.

$\mathrm{Al}$ respecto, se puede señalar sucintamente que los hechos que en forma literaria y metafórica se abordan en El Gallo Pitagórico, libro publicado en mayo de $1845,{ }^{2}$ se insertan de manera general en los álgidos años en que se desenvolvió y derrumbó el gobierno del general Antonio López de Santa Anna, instaurado entre 1841 y 1844 (su tercera y cuarta presidencias). Cabe señalar que aunque el polémico veracruzano y sus seguidores pudieron imponerse en ese lapso, intentando establecer un gobierno de sesgo dictatorial, ${ }^{3}$ su gestión estuvo jalonada por un continuo reposicionamiento de la oposición, encabezada por el grupo de los liberales moderados, el cual consiguió desplazar al caudillo de forma aparatosa con el movimiento del 6 de Diciembre de 1844 (o movimiento decembrista), y tomar a su vez el poder, reteniéndolo prácticamente durante todo el año de 1845. En este grupo, como legisladores, participaron activamente el autor de El Gallo Pitagórico, Juan Bautista Morales Olavarrieta (1788-1856), e Ignacio Cumplido Maroto (1811-1887), ${ }^{4}$

${ }^{1}$ Se advierte al lector que en las citas se ha conservado la ortografía original.

${ }^{2}$ El 16 de mayo de 1845 El Siglo Diez y Nueve anunció que la obra saldría a la venta una semana más tarde: “Avisos”, El Siglo Diez y Nueve, México, 16 de mayo de 1845, p. 4. Se trata de la primera edición: Juan Bautista Morales, El Gallo Pitagórico, México, Imprenta de Ignacio Cumplido, 1845.

${ }^{3}$ Will Fowler, "La tercera y cuarta presidencia de Antonio López de Santa Anna (18411844)”, en Will Fowler (coord.), Gobernantes mexicanos, México, Fondo de Cultura Económica, 2008, v. 1, p. 159-184.

${ }^{4}$ Sobre Morales como senador, véase Michael Costeloe, La república central en México, 1835-1846: "Hombres de bien" en la época de Santa Anna, México, Fondo de Cultura Eco- 
su editor e impresor, ${ }^{5}$ viéndose ambos beneficiados con el reacomodo político tras la debacle santannista. El primero obtuvo la gubernatura de Guanajuato y el otro permaneció en su escaño de diputado. ${ }^{6}$ Los intereses de ambos y de su grupo político se plasmaron en el libro y sus imágenes.

nómica, 2000, p. 298. En cuanto a Cumplido como diputado, véase El Siglo Diez y Nueve, México, 17 de agosto de 1844, n. 996, p. 4; esto explica la afirmación de Zarco en el sentido de que cuando se intentó disolver el Congreso de 1844, Cumplido fue el único impresor que se puso a disposición para imprimir un manifiesto para denunciar los hechos; Francisco Zarco, “El señor D. Juan Bautista Morales”, en Juan Bautista Morales, El Gallo Pitagórico: colección de artículos crítico-políticos y de costumbres, México, Imprenta de Ignacio Cumplido, 1857, p. I-XLVII, p. XII.

${ }^{5}$ Juan Bautista Morales fue un criollo de origen modesto, nacido bajo el orden novohispano, para quien la Independencia significó la posibilidad de un ascenso social y político, pues, formado como abogado, fue uno de los legisladores del ala federalista en el primer Congreso Constituyente de México (el que dio vida al código de 1824), lo que le sirvió de plataforma para alcanzar un cargo de fiscal en la Suprema Corte de Justicia, instancia en la que fue escalando, y combinando con otras actividades: catedrático en San Ildefonso, diputado, senador, gobernador de Guanajuato, magistrado y al final de su vida presidente del propio poder judicial. En su trayectoria, cabe destacar su activa participación política en la década de los cuarenta dentro del ala liberal moderada liderada por Manuel Gómez Pedraza; el temprano contacto de Morales con este personaje (desde los años veinte) acaso indique el origen de dicho grupo político, el cual se conformaría como tal hasta fines de los años treinta del siglo XIX. Para datos biográficos de Morales, entre otros, cfr. Jesús Rodríguez Frausto, "Juan Bautista Morales: abogado, político, periodista y escritor”, Biografías, 32 al 36, 1960, s. n. p.; Zarco en la segunda edición del libro: Zarco, "El señor D. Juan Bautista Morales”, en Morales, El Gallo Pitagórico... (1857), p. Xviır. Félix Hernández del Ángel (comp.), Textos reunidos del licenciado Juan Bautista Morales (1788-1856). Documentos cartas literatura, Chalco, edición del autor, 2007, y Félix Hernández del Ángel (comp.), Textos reunidos del licenciado Juan Bautista Morales (1788-1856). Política y sociedad, Chalco, edición del autor, 2016. Sobre Cumplido, entre otros estudios, véanse Irma Lombardo García, El siglo de Cumplido: la emergencia del periodismo mexicano de opinión, 1832-1857, México, Universidad Nacional Autónoma de México, Instituto de Investigaciones Bibliográficas, 2002, y, María Esther Pérez Salas Cantú, "Los secretos de una empresa exitosa: la imprenta de Ignacio Cumplido”, en Laura Suárez de la Torre (coord.), Constructores de un cambio cultural: impresores-editores y libreros en la ciudad de México: 1830-1855, México, Instituto de Investigaciones Dr. José María Luis Mora, 2003, p. 101-181.

${ }^{6}$ Carlos María de Bustamante escribió: “Está elegido por el gobierno, gobernador de Guanajuato, don Juan Morales, o sea, 'El Gallo Pitagórico'. Puesto de gobernador entiendo que será un faccioso, y de escritor del Siglo, un excelente hombre [...] Non ommia omnibus" (Carlos María de Bustamante, Diario histórico de México, CD-ROM, ed. de Josefina Z. Vázquez y Héctor Cuauhtémoc Hernández Silva, México, Centro de Investigaciones y Estudios Superiores en Antropología Social/El Colegio de México, 2001 y 2003, CD 2, 13 de febrero de 1845). En cuanto a que Cumplido continuó como diputado hasta diciembre de 1845, véase Lombardo, El siglo de Cumplido..., p. 59. 
Héroe versus villano

Entre las estrategias que los santannistas y sus opositores esgrimieron para legitimar respectivamente su actuación ante la opinión pública estuvo la defensa o la puesta en entredicho de las acciones e imagen de López de Santa Anna. Al margen de sus desaciertos, ${ }^{7}$ el gobierno santannista del periodo, por un lado, puso en marcha medidas administrativas que le merecieran la aprobación general (una reforma educativa y un amplio proyecto cultural, además de medidas para ordenar la economía nacional y conciliar los intereses de corporaciones tradicionales, como el ejército y la Iglesia, con la modernización paulatina del Estado mexicano), ${ }^{8}$ y por otro, promovió el culto a su líder, proyectándolo como benefactor y héroe, mediante artículos periodísticos, discursos, recitales, fiestas, y una diversidad de imágenes como retratos, pinturas de historia, litografías, estatuas, monumentos, etcétera. ${ }^{9}$ Asimismo, para consolidar el resultado de estas estrategias, tuvo gran cuidado en acallar las críticas.

Por su parte, la oposición subrayó los errores de la administración santannista en una serie de expresiones de carácter diverso: rumores (el diario personal del apasionado Carlos María de Bustamante, connotado político e historiador, permite atisbar en muchos de ellos), ${ }^{10}$ manifestaciones de carácter popular -incitadas o no- como folletos y hojas sueltas con versos satíricos ${ }^{11}$ o los judas que se quemaban en Semana Santa, y que en marzo de 1842 adoptaron la coja figura del general, ${ }^{12}$ hasta las críticas expresadas

${ }^{7}$ Independientemente de la satanización que de Santa Anna hizo mucha de la historiografía, éstos son reconocidos por un historiador como Will Fowler que, más desprejuiciado, aborda al personaje mostrando sus claroscuros; Fowler, "La tercera y cuarta presidencia de Antonio López de Santa Anna...”.

${ }^{8}$ Fowler, "La tercera y cuarta presidencia de Antonio López de Santa Anna...", y Montserrat Galí, Cultura y política en el México conservador. La Lotería de la Academia Nacional de San Carlos (1843-1860), Puebla, Benemérita Universidad Autónoma de Puebla, Instituto de Ciencias Sociales y Humanidades "Alfonso Vélez Pliego/Ediciones de Educación y Cultura, 2012.

${ }^{9}$ Ninel Hipatia Valderrama Negrón, El fomento de la policía de ornato en la república de 1841-1844, tesis para obtener el grado de licenciada en Historia, México, Universidad Nacional Autónoma de México, 2010.

${ }^{10}$ Bustamante, Diario histórico de México..., CD 2.

${ }^{11}$ Cfr. Guillermo Prieto, Memorias de mis tiempos, México, Porrúa, 1985 (Colección "Sepan cuantos...", n. 381), p. 240, y Bustamante, Diario histórico de México..., CD 2, 27 de enero de 1842 y 10 . de enero de 1845. Un número importante de ellas se conserva en colecciones nacionales y extranjeras.

${ }^{12}$ Bustamante, Diario histórico de México..., CD 2, 27 de marzo de 1842. 
por la oposición en su propia prensa, en la tribuna y en general en sus discursos, donde quiera que los expresaran. En cuanto a las caricaturas que se hicieron en contra del general, y que se han conservado, empezaron a circular hasta el momento en que perdió el control político y ya se preveía su caída. Fue también hasta ese momento cuando la ira popular se volcó en actos de franca iconoclasia en contra de los monumentos y las imágenes laudatorias de Santa Anna: mientras que en Querétaro se le dedicaron caricaturas irreverentes y hasta albureras, ${ }^{13}$ en la ciudad de México y en la de Puebla, como se sabe, sus monumentos, o fueron destruidos, o sometidos a actos de menoscabo y denigración pública. Según Michael Costeloe, se trató probablemente de "la más humillante de sus derrotas [...] cuando el culto a su personalidad, cuidadosa y largamente forjado por él, se vino literalmente al suelo". ${ }^{14}$

En este periodo se confrontaron, por lo tanto, visiones contrapuestas de Santa Anna como héroe y villano, y El Gallo Pitagórico abonó en la segunda. Sus artífices, Morales y el editor Cumplido, habían tenido un lugar muy destacado en el grupo antagonista al general, y particularmente en la disputa periodística desde El Siglo Diez y Nueve, el principal periódico de oposición y medio de expresión de los liberales moderados, del cual el primero era redactor en jefe y el segundo propietario. Ahí, entre enero de 1842 y septiembre de 1844, Morales publicó seis de los siete extensos artículos que conformarían posteriormente la edición ilustrada de El Gallo Pitagórico, ${ }^{15}$ los cuales, junto con una infinidad de escritos más, entre ellos los publicados en otros periódicos, sirvieron para cuestionar las acciones de la administración de Santa Anna y para dar fuerza y promover los puntos de vista de los moderados. Conforme la oposición cobraba o perdía fuerza, la crítica en la obra de Morales fue más o menos evidente, pero fue siempre velada. Incluso en el último texto, publicado sólo al aparecer el libro, cuando el general ya había perdido el mando y se encontraba prisionero en Perote esperando ser juzgado, la alusión aunque más constante y

${ }^{13}$ Carlos María de Bustamante, Apuntes para la historia del gobierno del general don Antonio López de Santa Anna, edición facsimilar, pról. de Carmen Vázquez Mantecón, México, Instituto Cultural Helénico/Fondo de Cultura Económica, 1986, p. 388.

${ }^{14}$ Costeloe, La república central en México..., p. 274.

${ }^{15}$ Se publicaron respectivamente el 26 de enero, el 30 de abril y 22 de junio de 1842 , el 5 de junio y 6 de noviembre de 1843, y el 21 de septiembre de 1844 . El publicado el 30 de noviembre de 1844 no se incluyó en el libro, que en cambio tuvo como artículo final otro que no se había publicado previamente. 
evidente, mantuvo su carácter elusivo; en este artículo Morales lo hizo encarnar metafóricamente en Cola de Plata, ${ }^{16}$ según vox populi su gallo favorito, plasmando así, sin mencionar su nombre, una de las importantes recriminaciones que se le hicieron por entonces al general: su gusto irresponsable por el jolgorio y el dispendio a costa del erario público. ${ }^{17}$ Asimismo, se eludió representar de forma directa en las ilustraciones de El Gallo Pitagórico la fisonomía de Santa Anna, que sólo se plasmó discretamente en un grabado de la contracubierta de los forros que acompañaron las entregas, conservados en muy pocos de los ejemplares que existen del libro, en donde se le muestra como un gallo cojo (ejecutado por el entonces grabador Rafael de Rafael, ${ }^{18}$ lámina 1). Más allá de esta salvedad, la imagen que enseguida revisaremos es una clara muestra de la tendencia a aludir al general de forma indirecta, y analizarla dentro el contexto histórico permitirá entender el porqué de dicha actitud.

\section{La figura del Faetón político en 1844}

La estampa dibujada por Plácido Blanco ${ }^{19}$ en que se representa la caída del gobierno santannista mediante el símil de la caída de Faetón o Faetonte, y

${ }^{16}$ Morales lo describió así: "era un Gallo, á quien llamaban Cola de plata, y que por las peleas que habia ganado habia adquirido el sobrenombre de Tripas de oro y era puntualmente el archi-gallo, ó jefe de los demas, de regular estatura, ojos vivos, mirar perspicaz, mutilado de un espolon, y brillantemente emplumado [...]"; Juan Bautista Morales, El Gallo Pitagórico (1845), p. 245. En el nombre, recogía una vieja, chusca y conocida anécdota que corría desde la primera presidencia de Santa Anna, una década atrás, narrada con ligeras y amenas variantes, por "un ciudadano respetable" a Fanny Calderón y por Carlos María de Bustamante en su diario, según la cual, Cola de Plata era el nombre de uno de los gallos favoritos del general, quien, por atenderlo, había llegado al extremo de salirse de una importante reunión con su gabinete; Madame Calderón de la Barca, La vida en México durante una residencia de dos años en ese país, México, Porrúa, 1997, p. 376, y Bustamante, Diario histórico de México..., CD 1, día 30 de diciembre de 1834.

${ }^{17}$ Respecto de este tema, pero en relación con su conducta sexual, se puede ver Helia Bonilla, “Santa Anna y los agentes de la voluptuosidad”, en XXIX Coloquio Internacional de Historia del Arte, Miradas disidentes: género y sexo en la historia del arte, México, Universidad Nacional Autónoma de México, Instituto de Investigaciones Estéticas, 2007, p. 35-73.

${ }^{18}$ Rafael de Rafael fue un hombre polifacético que desempeñaría un papel muy destacado en la política y el medio editorial y cultural de México poco después; Galí Boadella, Cultura y política en el México conservador...

19 Aunque la lámina en su versión terminada carece de firma en 12 ejemplares de $E l$ Gallo Pitagórico revisados en distintos acervos, hay una versión en uno de los tres ejemplares 




Lámina 1. Grabado en madera de pie, atribuido a Rafael de Rafael, cuarta de forros o contracubierta de El Gallo Pitagórico, 1845

que se titula Que Júpiter con sus rayos los arrojara de cabeza al lago de Texcoco (lámina 2), es la más contundente en lo que se refiere a la significación política del libro, que dicho está, se publicó en 1845. En ella se celebra el cumplimiento de un deseo o advertencia que Juan Bautista Morales había expresado de forma velada dos años atrás, envuelto precisamente en esa

que se conservan en la Biblioteca Nacional de Antropología e Historia Dr. Eusebio Dávalos Hurtado del INAH, signada por Plácido Blanco, lo que indica que su nombre fue borrado de la imagen, quizá por políticas editoriales del editor Cumplido. Dicho ilustrador formó parte de la primera generación de litógrafos profesionales en México; Helia Emma Bonilla Reyna, El Gallo Pitagórico (1842-1845): estampa, imprenta y política en torno a Santa Anna, tesis de doctorado en Historia del Arte, México, Universidad Nacional Autónoma de México, Instituto de Investigaciones Estéticas, 2013. 


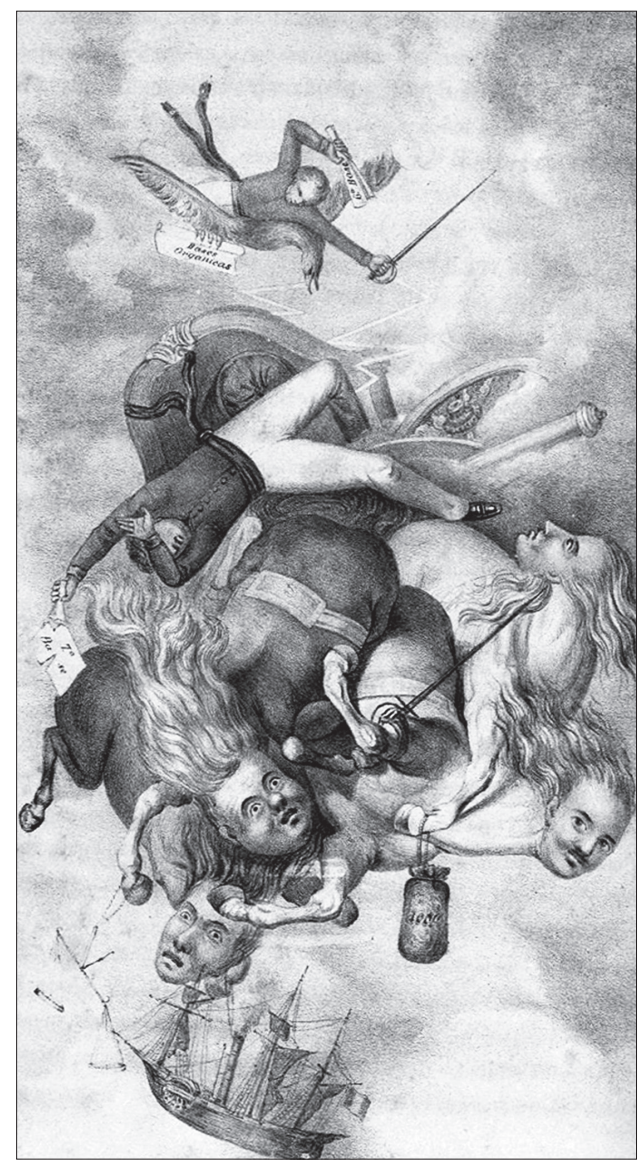

Lámina 2. Litografía de Plácido Blanco, Que Júpiter con sus rayos los arrojara de cabeza al lago de Texcoco, ilustración interior de El Gallo Pitagórico, 1845

conocida metáfora literaria, respecto de que quien llevaba las riendas del poder (no lo mencionó, pero evidentemente se refería a Santa Anna), podría ser arrojado del gobierno por sus errores políticos. Fue esto lo que auguró en un artículo de El Gallo Pitagórico, que publicó en junio de 1843 en El Siglo Diez y Nueve, y que al ser reimpreso en la versión final del libro, fue ilustrado con esta imagen; en dicho artículo, refiriéndose a la audacia que había tenido el inexperto y joven Faetón, o Faetonte, al haberse puesto a manejar el carro de Júpiter, su padre, decía:

Esta temeridad la vemos imitada en pequeño en todos los tiempos y naciones; pues toman las riendas de los gobiernos unos funcionarios tan ineptos para dirigirlos 
bien, como Faetonte para gobernar el carro del Sol. ¡Qué bueno seria que para escarmiento general, tuvieran todos los gobernantes ineptos la propia suerte que aquel jóven atrevido! ¡Qué Júpiter con sus rayos los arrojara de cabeza al caudaloso Eridano, ó aunque fuera al lago de Texcoco! ${ }^{20}$

Por lo tanto, el dibujante, muy probablemente instruido por Morales, ${ }^{21}$ partió del motivo que éste utilizó en su texto dos años atrás, pero que en la imagen se reactualizaba para comentar y celebrar, y aún más, legitimar un suceso mucho más reciente. Es decir, que mientras el texto, por los sucesos a que se refería estaba anclado en el año de 1843 (aunque de alguna manera también se reactualizaba al ser publicado en el nuevo contexto), la estampa actuaba de forma independiente para hablar de lo que había sobrevenido después, es decir, de la efectiva y aparatosa caída de Santa Anna a fines de 1844, y con ello el cumplimiento del deseo de Morales.

Desde el punto de vista de la oposición, eran muchas las cosas que en una imagen como la que ahora se cita se le podrían haber achacado al depuesto militar para explicar el porqué de su debacle en 1844. Varias de ellas fueron enunciadas en el resto de El Gallo Pitagórico y sus imágenes, ${ }^{22}$ pero también en varias caricaturas anónimas que circularon por entonces, y que se refieren específicamente a la derrota del polémico general en 1844 y a los hechos precedentes o subsecuentes; en casi todas éstas, al igual que en la imagen de Faetón, se aludió a su degradante caída, ${ }^{23}$ pero en la totalidad de ellas, en mayor o menor grado, asoma la fisonomía de Santa Anna, generalmente con su pata de palo que lo hace inconfundible. Por el contrario, esta explicitud no ocurre ni en la estampa de Faetón, ni en ninguna otra de El Gallo Pitagórico, salvo, de forma discreta, en la ya mencionada que aparece en la contracubierta (lámina 1). Además, en lo que pareciera

${ }^{20}$ Erasmo Luján, “Remitido/ El congreso de los dioses”, El Siglo Diez y Nueve, México, 5 de junio de 1843, p. 1, y Morales, El Gallo Pitagórico (1845), p. 123. Erasmo Luján era uno de los seudónimos de Morales.

${ }^{21}$ En estos años, los que sufragaban las ilustraciones eran quienes determinaban su sentido; respecto a El Gallo Pitagórico, Francisco Zarco dejó testimonio de que, al menos para su segunda edición de 1857, Morales fue quien en efecto instruyó al dibujante -Zarco, “El señor D. Juan Bautista Morales”, en Morales, El Gallo Pitagórico... (1857), p. XXXVII-, por lo que es más que probable que ocurriera lo mismo con la primera edición.

${ }^{22}$ Bonilla Reyna, El Gallo Pitagórico (1842-1845): estampa...

${ }^{23}$ Véase Rafael Barajas Durán (el Fisgón), Historia de un país en caricatura: Caricatura mexicana de combate, 1821-1972, México, Fondo de Cultura Económica, 2013, p. 110-121, y Bonilla Reyna, El Gallo Pitagórico (1842-1845): estampa... 
una especie de autocensura, a esta lámina del Faetón no se le puso el título que inicialmente se le pensaba asignar, según el anuncio con que se promocionó el libro, el cual resultaba mucho más explícito respecto de lo ahí representado: Caida del Faetonte político, ó sea de la administracion revolucionaria. ${ }^{24}$

¿Y cuál fue la razón de todo lo anterior? Probablemente el temor de Morales - aunque quizá también de sus correligionarios-al posible regreso del general, el cual se expresó en una carta que el periodista y abogado envió al también moderado Mariano Riva Palacio y que publicó en El Siglo Diez y Nueve el 22 de abril de $1845,{ }^{25}$ es decir, un mes antes de que la litografía apareciera junto con el libro. Dicho temor estaba fundamentado seguramente, lo que puede constatarse porque el 7 de junio, días después de la aparición de El Gallo Pitagórico, estalló una revuelta que pretendía derribar al gobierno moderado de José Joaquín Herrera, del que Morales, como gobernador de Guanajuato, formaba parte, y en la cual estuvieron involucrados ni más ni menos que José Ignacio Basadre y Valentín Canalizo, el exministro de Guerra de Santa Anna y su expresidente interino (en septiembre de 1844 Santa Anna maniobró para dejar a Canalizo al mando, aunque restringido, mientras se retiraba a una de sus haciendas en Veracruz, desde donde enviaba instrucciones). ${ }^{26} \mathrm{El}$ propio caudillo, enterado de que se estaba fraguando dicha revuelta, había intentado vanamente hacer tiempo antes de salir desterrado. ${ }^{27}$

Por lo que se refiere a la iconografía, en Que Júpiter con sus rayos los arrojara de cabeza al lago de Texcoco se utilizó un motivo conocido al menos por aquéllos que habían leído las Metamorfosis de Ovidio. Respecto de los temas mitológicos, Francisco de la Maza afirma que en la Nueva España, en "los arcos triunfales aparecían siempre los dioses y los héroes de Grecia y de Roma -instruidos sus autores, sobre todo, en las Metamorfosis de Ovidio, libro clave en toda biblioteca-, salvo algunas excepciones"; ${ }^{28}$ el mito de Faetón como metáfora de mal gobierno había sido utilizado también en las

${ }^{24}$ El Siglo Diez y Nueve, México, 18 de mayo de 1845, p. 4.

${ }^{25}$ Morales, "Ministerio de Relaciones Exteriores, Gobernacion y Policia”, El Siglo Diez y Nueve, México, 22 de abril de 1845, p. 1; citada en Pedro Santoni, Mexican at Arms. Puro Federalists and the Politics of War, 1845-1848, Fort Worth, Texas Christian University Press, 1996, p. 49, notas 61 y 62 del capítulo II.

${ }^{26}$ Costeloe, La república central en México...

27 Toda esta interesante información es ofrecida en Santoni, Mexican at Arms..., p. 78-79.

${ }^{28}$ Francisco de la Maza, La mitología clásica en el arte colonial de México, México, Universidad Nacional Autónoma de México, Instituto de Investigaciones Estéticas, 1968 (Estudios y Fuentes del Arte en México, xxıv), p. 10. 
pinturas de las piras funerarias, ${ }^{29} \mathrm{y}$ en suma, había sido bien conocido en la cultura virreinal. Según la mitología grecorromana, Faetón era hijo del Sol (Apolo) y la Aurora (Clímene); su deseo fue conducir el carro de su padre durante un día pero su inexperiencia lo llevó a provocar una catástrofe, pues los caballos del carro del Sol, cuando descubrieron que su dueño no era el que los guiaba, se desbocaron provocando el incendio de la Tierra y por poco la eliminación del Universo. Júpiter, para evitar más trastornos, puso fin a la loca carrera disparando su rayo contra el carro que cayó convertido en bola de fuego sobre el río Erídano. ${ }^{30}$

Morales, quien en su juventud vivió el orden colonial y, según los testimonios de Guillermo Prieto y Carlos María de Bustamante era un hombre culto, ${ }^{31}$ había leído desde luego a Ovidio (a quien cita explícitamente en varias ocasiones en El Gallo Pitagórico e incluso parodia en el último de los artículos de su libro), ${ }^{32}$ y es probable que haya conocido también algunas representaciones visuales en que se recogían motivos de su obra; en particular, el pasaje de Faetón fue ampliamente ilustrado desde el siglo XVI por medio del grabado, en las diversas ediciones de las Metamorfosis, que a lo largo del tiempo inspiraron a diversos artistas como Rubens, Jan Eyck, Poussin, Reni, etcétera. ${ }^{33}$ Pero la imagen de El Gallo Pitagórico deriva en última instancia de La caída de Faetón, un bello dibujo de Miguel Ángel que se encuentra actualmente en la Royal Collection Trust en Londres (lámina 3). Por entonces, la forma en que en México podía accederse a obras del arte culto europeo era a través de reproducciones extranjeras, insertas en publicaciones de carácter diverso, o en hojas sueltas; por

${ }^{29}$ Ibidem, p. 26, 29, 94 y 188.

${ }^{30}$ La historia se relata en el libro segundo de Publio Ovidio Nasón, Metamorfosis, vers. rítmica y notas de Rubén Bonifaz Nuño, México, Universidad Nacional Autónoma de México, Instituto de Investigaciones Filológicas, 1979 (Bibliotheca Scriptorvm Graecorvm et Romanorvm Mexicana), p. 25-31.

${ }^{31}$ Prieto, Memorias de mis tiempos..., p. 201, y Bustamante, Apuntes para la historia..., p. 67.

${ }^{32}$ Morales, El Gallo Pitagórico (1845), p. 121 y 268.

${ }^{33}$ Ana Laura Iglesias, "El mito de Faetón: sobre el exceso, lo fugaz y la conducción. Reflexiones sobre el relato y su apropiación”, en Modernidades, la historia en diálogo con otras disciplinas, 2006, consultado en 2016 en http://www.ffyh.unc.edu.ar/archivos/modernidades_a/IV/DEFINITIVOS/Articulo_Iglesias.htm\#_ftn13, y Elisa Barranco Lorente El mito de Faetón en ediciones ilustradas de las Metamorfosis de Ovidio (siglos XVI y XVII), trabajo fin de máster en Estudios Avanzados en Patrimonio Cultural: Historia, Arte y Patrimonio, Jaén, Universidad de Jaén, Centro de Estudios de Posgrado, 2016. Consultado en 2018 en http:// tauja.ujaen.es/bitstream/10953.1/4346/1/TFM_Barranco_Lorente_Elisa\%20Mar\%C3\% ADa.pdf 


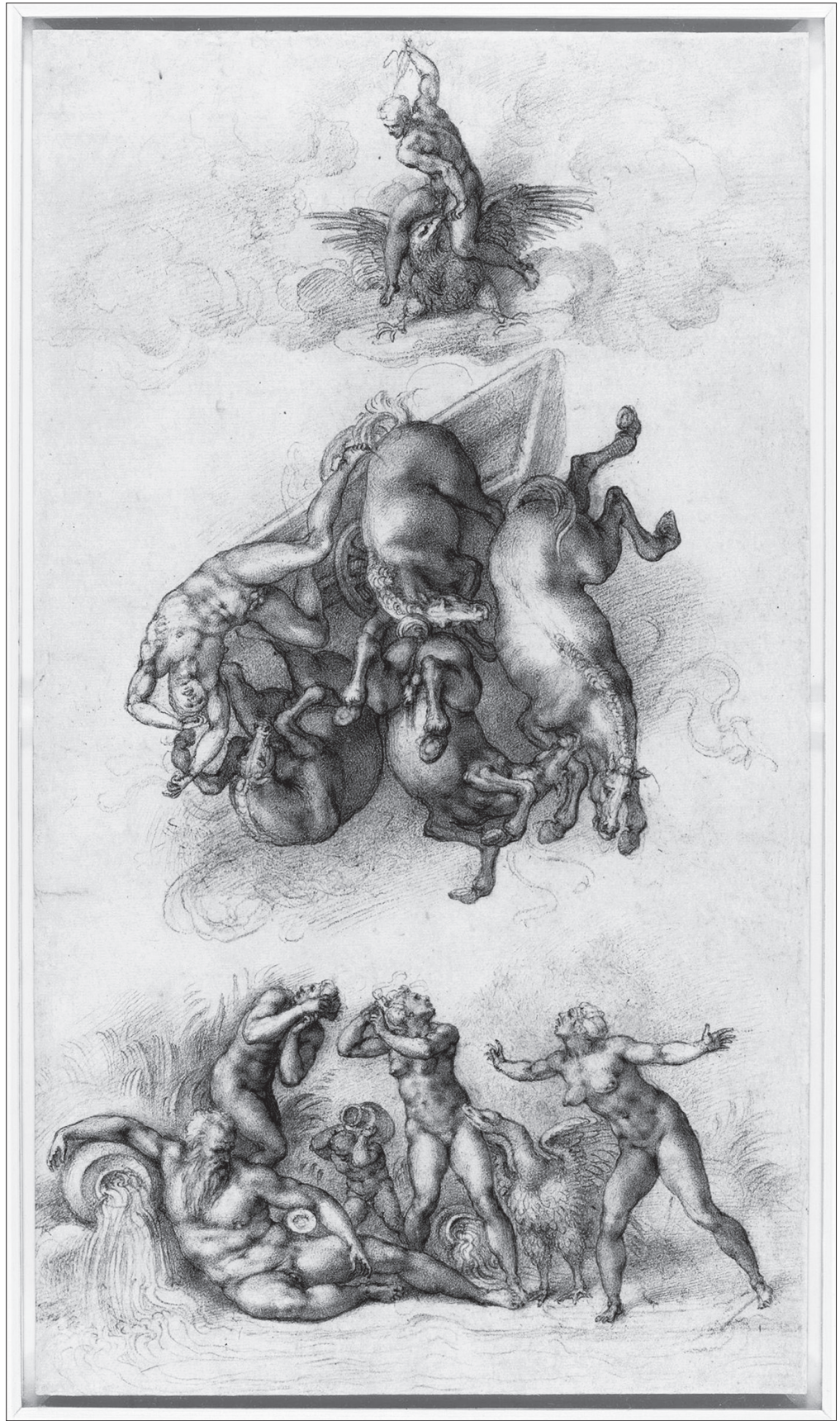

Lámina 3. Dibujo de Miguel Ángel, La caída de Faetón, 1533. Tiza negra, $41.3 \times 23.4 \mathrm{~cm}$ (hoja de papel) | RCIN 912766 . Royal Collection Trust / (c) Her Majesty Queen Elizabeth II 2018 
ejemplo, en junio de 1842 en el Diario del Gobierno se anunció a la venta una "Galería inglesa ó coleccion de los cuadros de los mejores maestros, que se conserva en la galería real de Lóndres, magníficos grabados en 80 láminas de acero, encuadernación de lujo". ${ }^{34}$ Sin embargo, no se puede descartar que entre el dibujo del genio italiano y la imagen del Faetón en El Gallo Pitagórico haya habido una imagen intermedia, es decir, que su dibujante hubiese partido en realidad de alguna estampa en que el dibujo del gran artista del Renacimiento fuera copiado o reinterpretado, y al respecto baste reiterar que dicho dibujo inspiró algunas de las ilustraciones de las ediciones impresas de las Metamorfosis. Como sea, independientemente del nivel de familiaridad que, hacia el motivo de Faetón, hubiese en esa época entre los mexicanos promedio que leían la prensa y las obras sobre política, su comprensión o reconocimiento al ver la imagen se facilitó sin duda porque en el propio libro El Gallo Pitagórico, que ésta ilustraba, se hacía referencia explícita a él en el párrafo arriba citado.

En cuanto a la imagen de Faetón, ¿̇cuál fue la principal acusación que lanzó en ella Morales, el autor del libro? Iremos por partes. En cuanto a los personajes representados en la imagen, a los ojos de un observador actual, y con la información asequible, se revelan varias cuestiones que fueron evidentes en la época, pero también ciertas voluntarias ambigüedades, y no sabemos si estas últimas fueron fácilmente resueltas por los contemporáneos que leyeron y vieron las estampas del libro escrito por Morales. ${ }^{35}$ Como sea, dejaremos esto último para el final, y empecemos con las evidencias.

34 “Avisos”, Diario del Gobierno de la República Mexicana, México, 26 de junio de 1842, p. 228. Dado que el dibujo original de Miguel Ángel se conserva en la Royal Collection Trust en Londres desde 1810, sería interesante saber si estuvo entre las obras reproducidas en dicha galería, pero no he encontrado más información sobre esto.

${ }^{35}$ Resulta difícil medir la recepción o impacto que pudo tener la obra y determinar a quiénes estuvo dirigida, sin embargo se pueden señalar algunos datos que podrían dar algunas luces al respecto. Aunque nada se sabe sobre su tiraje, debió ser relativamente alto, pues resulta significativo el hecho de que el libro se localice en un gran número de bibliotecas públicas y de colecciones privadas. Inicialmente, al salir a la venta, se ofreció en 18 reales (es decir, dos pesos y dos reales); si se considera que en 1842 el sueldo mensual de una recamarera era de 3 o 4 pesos al mes, es decir, 24 o 32 reales, y el de un cochero 15 pesos, es decir 120 reales, y que un pavo costaba 1 peso y medio (María José Esparza Liberal, "Los calendarios mexicanos del siglo xıx, una publicación popular", Boletín de Monumentos Históricos, Instituto Nacional de Antropología e Historia, México, v. 18, 2010, p. 32-146, p. 137), podemos observar que el libro, aunque no muy barato, bien podría haber sido adquirido por gente de escasos recursos, pero no por quienes tuvieran un salario demasiado bajo. 
Los defenestrados ministros del Faetón santannista

en diciembre de 1844

Parte de la información nos ayuda a constatar que, efectivamente, los cuatro caballos en la caricatura representan a los caídos cuatro ministros de Santa Anna, algunos de los cuales habían asumido sus cargos apenas unos días antes de que el general fuera expulsado de la suprema magistratura. Como ya se ha señalado, los caballos tienen rostros y atributos que permiten identificarlos; ${ }^{36}$ a tres de ellos, de una de sus patas, les cuelga un simbólico elemento que los vincula a las carteras que respectivamente habían ocupado: al exministro de Justicia, Manuel Baranda, una balanza; a Antonio Haro y Tamariz, exministro de Hacienda, una bolsa de dinero; a Manuel Crecencio Rejón, exministro de Relaciones, un barquito; en cuanto al exministro de Guerra, José Ignacio Basadre, en una de sus patas sostiene una espada. Las caras de todos ellos eran bien conocidas al menos por la turba que asistía a las sesiones del Congreso y que a menudo los abucheaba. ${ }^{37}$ Morales, quien se había desenvuelto desde muchos años antes en las altas esferas de la política, los conocía a todos, y a algunos desde mucho tiempo atrás; él mismo, en tono irónico, afirmó en El Gallo Pitagórico que los conocía "como si los hubiera parido". ${ }^{38}$

Entre los rostros, sobresale el mofletudo e inconfundible del exministro de Justicia e Instrucción Pública, Manuel Baranda (quien, al igual que Morales, era también guanajuatense, había estudiado en el mismo colegio y había sido asimismo gobernador del departamento), ${ }^{39}$ según podemos confrontar con un retrato que reproduce en un libro el historiador Agustín Lanuza $^{40}$ (cotéjense láminas 4 y 5). Durante estos años Baranda había trabajado al lado de Santa Anna, enfrentándose al grupo de Morales; como ministro de Justicia, había maniobrado exitosamente para desplazar a otros miembros del gabinete, y su papel en la confrontación entre el ejecutivo y

${ }^{36}$ Barajas Durán (el Fisgón), Historia de un país en caricatura..., p. 105-107. Si bien, yo difiero respecto de la identidad que el autor asigna a uno de ellos.

${ }^{37}$ Cfr. Bustamante, Apuntes para la historia..., p. 350, y Carlos A. Echánove Trujillo, La vida pasional e inquieta de don Crecencio Rejón, México, Sociedad Mexicana de Geografía y Estadística, 1941 (Boletín de la Sociedad de Geografía y Estadística, t. 53, n. 1 al 12), p. 329 y 330 .

${ }^{38}$ Morales, El Gallo Pitagórico (1845), p. 265.

${ }^{39}$ Agustín Lanuza, Historia del Colegio del Estado de Guanajuato, México, M. León-Sánchez imp., 1924, p. 52 y 54.

${ }^{40}$ Lanuza, Historia del Colegio del Estado..., p. 51. 


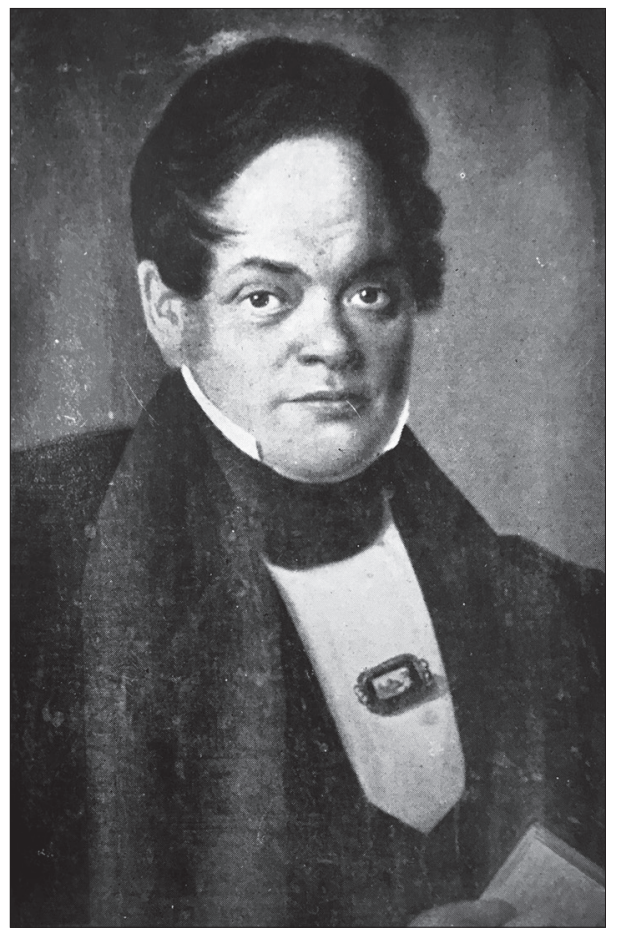

Lámina 4. Retrato de Manuel Baranda, tomado del libro de Agustín Lanuza, Historia del Colegio del Estado de Guanajuato, 1924

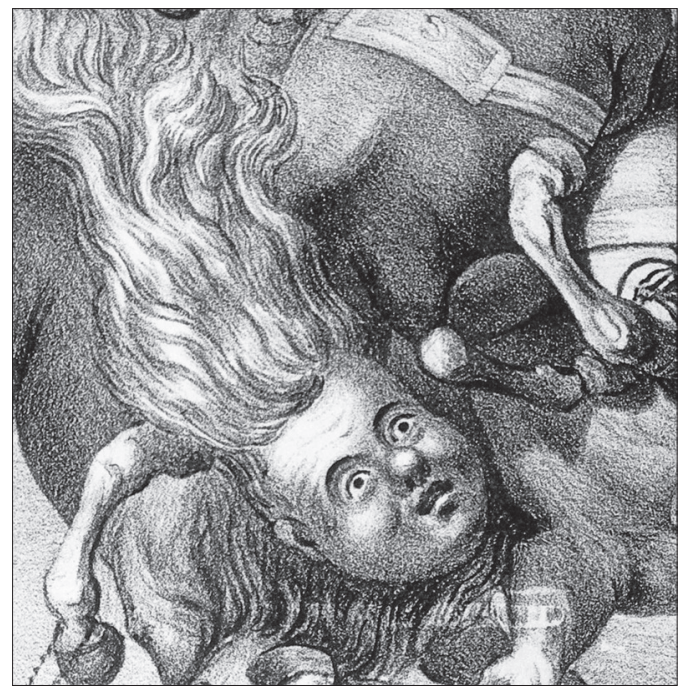

Lámina 5. Litografía de Plácido Blanco, Que Júpiter con sus rayos los arrojara de cabeza al lago de Texcoco, ilustración interior de El Gallo Pitagórico, 1845, detalle 
el legislativo había sido relevante, llegando incluso a escribir, según parece, algunos polémicos artículos en el Diario del Gobierno para desacreditar a este último, ${ }^{41}$ además de que acusó al propio Juan Bautista Morales ante el Gran Jurado de las Cámaras cuando éste publicó un artículo para defender al Congreso del posible golpe de Estado que sobre él se cernía, y de lo cual Morales pudo salir airoso. ${ }^{42}$

Por su parte, en las páginas de El Gallo Pitagórico, su autor habló del carácter supuestamente ambicioso y traicionero de Baranda (coincidiendo en ello con Carlos María de Bustamante, ${ }^{43}$ quien por entonces, como diputado centralista, militaba también en la oposición al santannismo), ${ }^{44}$ aludió a sus estratagemas para socavar a los otros ministros cuando afirmaba: "todavía se acuerda de sus travesurillas pasadas, pues desbancó a sus tres antiguos compañeros para apoderarse del ánimo de Cola de plata [Santa Anna] y mandar en gefe". ${ }^{45}$ Aunque sólo de paso, Morales se refirió también a los enfrentamientos que tuvo Baranda con el Congreso cuando, no tan elusivamente, afirmó que entre los cuatro gallos que acompañaban a Cola de Plata, había "uno de pico un poco romo [...] que cantaba muy recio principalmente cuando lo hacia desde las barandillas de las Cámaras"; ${ }^{46}$ si

${ }^{41}$ Cfr. Enrique Olavarría y Ferrari, México independiente, en Vicente Riva Palacio (coord.), et al., México a través de los siglos, 17a. ed., México, Cumbre, 1977, t. VII y viII, p. 85; José Ramón Malo, Diario de sucesos notables de José Ramón Malo (1832-1853), arreglados y anotados por el padre Mariano Cuevas, S. J., México, Patria, 1948, p. 245, y Bustamante, Apuntes para la historia..., p. 288-291.

${ }^{42}$ Al respecto, Bustamante afirmó: "En un preciosísimo artículo del Siglo se dijeron verdades duras, pero verdades que ofendieron á Santa-Anna; más Baranda á guisa de paladin se presentó en la palestra, denunció el artículo y resultó ser del Gallo Pitagórico, es decir, del senador D. Juan Morales. Siguió sus trámites el expediente, y llegado el dia de calificarlo en el gran jurado, acudió mucha gente á las galerías del senado tomando el pueblo interés en la absolución de la $[\mathrm{sic}]$ este gallo, que ha cantado divinamente y [sic] tonos variados: defendióse muy bien y salió absuelto con unanimidad de votos y de aplausos; el acusador no osó presentarse á sostener su acusacion, y gallo que huye de otro gallo en un palenque sufre una pena vergonzosa. Esta tapada tuvo lugar el dia 10 de setiembre de 1844", en Bustamante, Apuntes para la historia..., p. 293.

${ }^{43}$ Bustamante, Apuntes para la historia..., p. 291, 293 y 294.

${ }^{44}$ Bustamante era parte del grupo centralista, que por entonces se alió a los liberales moderados en contra de Santa Anna. Su actividad como diputado en este periodo se puede constatar tanto en su diario, como en la prensa; entre otras muchas noticias al respecto, $c f r$. Bustamante, Diario histórico de México..., CD 2, 26 de septiembre de 1844, y "Acta de la primera reunión para las juntas preparatorias de la Cámara de Diputados”, El Siglo Diez y Nueve, México, 20 de diciembre de 1843, p. 4.

${ }^{45}$ Morales, El Gallo Pitagórico (1845), p. 266.

${ }^{46}$ Morales, El Gallo Pitagórico (1845), p. 245. Las cursivas están en el original. 
bien de forma muy escueta, Morales se refería aquí, además, a una de las características sobresalientes de la fisonomía de dicho político, la cual se muestra asimismo en el personaje que lo representa en la estampa de Faetón. De hecho, esta característica física de Baranda fue señalada por otros de sus contemporáneos, y así, aparece en el comentario que un paisano suyo le hizo a Bustamante en 1833, en el que además, se anota una temprana asociación entre él y Santa Anna: "No veo buena la cosa, porque donde el gobernador Baranda se ha ido a acoger a Santa Anna, seguro la lleva; es hombre muy astuto, él es chato de configuración, pero sus narices huelen mucho [...]". ${ }^{47}$

Varios testimonios nos pueden ayudar para argumentar que otro de los rostros sobresalientes en la imagen es el de José Ignacio Basadre (lámina 6), el ministro de Guerra en la última hora de aquella administración de Santa Anna, y por largos años hombre de su círculo de colaboradores y amigos. ${ }^{48}$ Respecto de su fisonomía, y a la forma en que respondió ante al Congreso de 1844, al que pertenecían Morales y el propio Bustamante, este último comentó:

Es el [sic] Basadre un hombre de hermosa figura, alto, de bellos y negros ojos; tiene la circunstancia de poseer un entendimiento claro; habla y se esplica felizmente; pero estas bellas partes esteriores no corresponden á las morales, por lo que no está bien querido, y tanto que el mayor desatino que pudo cometer Santa-Anna para desacreditar su gobierno, fue nombrarlo ministro, y por lo que todos le anunciaron su pronta caida. Habló a la cámara en tono tan destemplado como pudiera un sargenton á una escuadra de reclutas, dándoles de palos. Desde este momento conocimos que la disolucion del congreso seria pronta é indefectible; mas nada nos arredró para seguir con paso firme la senda constitucional, decididos á salvar la nacion aunque fuese derramando nuestra sangre en los destierros ó en los patíbulos. ${ }^{49}$

${ }^{47}$ Bustamante, Diario histórico de México..., CD 1, 26 de septiembre de 1833.

${ }^{48}$ Respecto de la temprana asociación de Basadre con Santa Anna, véase Michael Costeloe, La primera república federal de México (1824-1835). Un estudio de los partidos políticos en el México independiente, 2a. reimp., México, Fondo de Cultura Económica, 1996, p. 205, nota 91. Basadre mantuvo su amistad con Santa Anna al parecer por lo menos hasta 1853 (última vez en que asumió el poder), según testimonio de Prieto, quien dice que era entonces "de sus más íntimos", y que cuidaba de aleccionarlo para que no dijera barbaridades; Prieto, Memorias de mis tiempos..., p. 344 (cierto es, como sea, que en ocasiones, en sus memorias, Prieto confunde fechas).

${ }^{49}$ Bustamante, Apuntes para la historia..., p. 351. 


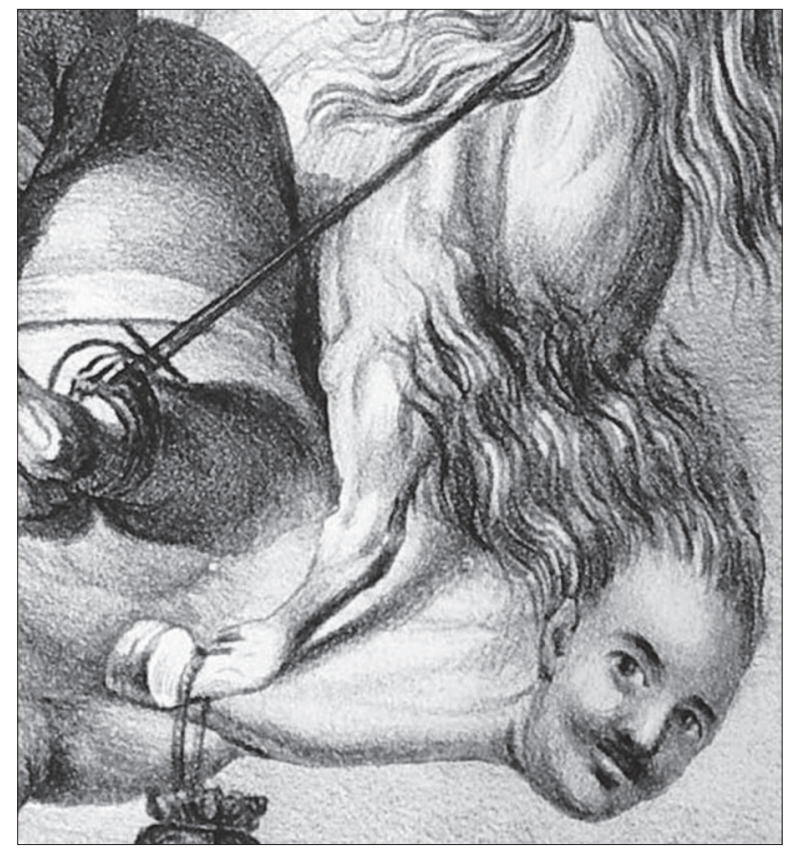

Lámina 6. Litografía de Plácido Blanco, Que Júpiter con sus rayos los arrojara de cabeza al lago de Texcoco, ilustración interior de El Gallo Pitagórico, 1845, detalle

Lo dicho respecto de la fisonomía y carácter de Basadre, lo confirma Prieto en varios puntos de sus memorias, refiriéndose a él además como apostador y calavera, comenta que entre varios conocidos políticos, detenidos en 1839 por conspirar supuestamente en favor de la federación "Basadre sobresalía en el grupo por su aire marcial, sus grandes y espresivos ojos negros, por su continente majestuoso" ${ }^{50}$ Los ojos de Basadre fueron por lo visto un rasgo sobresaliente de su fisonomía, por lo que años atrás, cuando era diputado por Veracruz, el irreverente periódico El Toro se refirió a él en tono menos halagüeño, como "Pepa Ignacia la Ojona". ${ }^{51} \mathrm{Y}$ en efecto, en la estampa de El Gallo Pitagórico son un rasgo notorio del rostro con que se le representó.

${ }^{50}$ Prieto señala varios aspectos que indicarían el porqué del desprestigio que tenía la opinión pública respecto de Basadre: "era un caballero legendario; grandes ojos negros, porte dramático, palabra seductora, archivo de anécdotas y aventuras del gran mundo; ornato de la culta sociedad europea... en el fondo, el arbitrista, el esclavo de Birján, el émulo del baroncito Faublas y de Gustavo el calavera”; Prieto, Memorias de mis tiempos..., p. 157 y 251.

${ }^{51}$ Bustamante, Diario histórico de México..., CD 1, 6 de agosto de 1829. 
Respecto de las "culpas" que Morales hizo recaer sobre Basadre para que apareciera en la imagen de Faetón junto con el resto del gabinete con que había colaborado, y para justificar el que en ese momento estuviera siendo juzgado, afirmó en El Gallo Pitagórico que había querido "matar políticamente a mas de cien gallos representantes", ${ }^{2}$ es decir, deshacerse del Congreso. Y efectivamente Basadre había emitido, junto con Vicente Canalizo, presidente interino; Crecencio Rejón, ministro de Relaciones, y dos generales más un decreto, el 29 de noviembre, con el fin de suspender las sesiones del legislativo, ${ }^{53}$ y el día que los legisladores encontraron las puertas de la Cámara custodiadas por soldados y subieron a hablar con Canalizo fue Basadre quien los recibió, informándoles que las sesiones habían sido suspendidas para evitar desmanes, ${ }^{54}$ lo cual hizo en forma petulante, según Bustamante. ${ }^{55}$

Coincidiendo de nuevo con éste, y aludiendo a su condición militar, Morales dijo que "era un gallazo muy erguido y petulante, mirar altanero, las plumas de la barriga verdes" y añadió "que habia jugado algunas tapadas en Francia, y de las que no pudo salir bien sino huyendo". ${ }^{56}$ Se refería con esto a hechos bien conocidos en la época, relativos al cuestionado desempeño de Basadre en un cargo diplomático, que se decía había usufructuado para divertirse escandalosamente en París, en donde por despilfarro tuvo que huir de sus acreedores falsificando una firma, por lo que terminó en una cárcel para estafadores. ${ }^{57}$ De ahí que Carlos María de Bustamante se preguntara, en la intimidad de su diario, qué pensarían los franceses al enterarse de que ese hombre desconceptuado, fugitivo de la cárcel de Santa Pelagia, "a donde lo condujeron sus traperías", hubiera obtenido el cargo de ministro. ${ }^{58}$

Tan conocido era en la época Basadre, como hombre público y amigo de Santa Anna, que a Morales le bastó con aludir a estos hechos para traerlos a colación. No obstante hoy no existe ninguna biografía, y de él apenas

52 Morales, El Gallo Pitagórico (1845), p. 245.

${ }^{53}$ Echánove, La vida pasional e inquieta..., p. 341 y 342. Los generales eran Mariano Salas y Manuel Céspedes.

${ }^{54}$ Echánove, La vida pasional e inquieta..., p. 348.

55 Bustamante, Apuntes para la historia..., p. 352.

${ }^{56}$ Morales, El Gallo Pitagórico (1845), p. 245. La palabra “tapadas” se usaba para referirse a las peleas de gallos.

57 "Galería de hombres célebers [sic]. (Continúa.) Biografia de don José Ignacio de Basadre”, El Monitor Republicano, México, 1o. de octubre de 1849, suplemento al n. 1633.

${ }^{58}$ Bustamante, Diario histórico de México..., CD 2, 23 de noviembre de 1844. 
se conoce un retrato, además del que caricaturizado aparece precisamente en la estampa ahora citada; ${ }^{59}$ se trata de un óleo firmado por José María García, pero debe ser tardío, pues en él se ve al personaje envejecido, con poco cabello y subido de peso, ya sin la galanura que encomiaron sus contemporáneos, ${ }^{60}$ pero que en todo caso no parece imposible que pueda corresponder, con años de diferencia, al rostro plasmado en el citado detalle de la litografía de El Gallo Pitagórico.

Para terminar con Basadre, cabe mencionar que aunque había asumido su cargo de ministro sólo tres días antes de que se emitiera el decreto para clausurar el Congreso, y once días antes de que éste a su vez triunfara sobre Santa Anna con el movimiento del 6 de Diciembre, ya desde los meses anteriores había estado preparando el ataque al legislativo junto con los principales miembros del gobierno del caudillo, y tal vez particularmente con Baranda. Bustamante comenta al respecto que, cuando empezaron las descalificaciones entre el Congreso y el gabinete, había circulado un impreso titulado Mientras haya congreso, no puede haber progreso, que se creyó salido de Tacubaya y se atribuyó justamente al mencionado militar; ${ }^{61}$ con este testimonio coincide también el de otro de los legisladores, José Ramón Malo, quien en su diario escribió, por los mismos días, el 24 de julio de 1844, que se empezaba ya a anunciar que el Congreso sería disuelto y que Basadre estaba encargado de escribir en favor de esta medida. ${ }^{62}$ Malo, además, señala que Basadre, junto con Baranda fueron a ver a Santa Anna ya avanzado el mes de octubre del mismo año de 1844, es decir, al momento en que se estaban haciendo los tensos reacomodos en el gabinete, lo que indicaría una particular cercanía entre ambos. ${ }^{63}$

Respecto de los otros dos exministros, Antonio Haro y Tamariz (de Hacienda) y Manuel Crecencio Rejón (de Relaciones), podemos identi-

59 Desafortunadamente se ha extraviado otro retrato suyo que se resguardaba en lo que fue el legajo 3-7 de la Colección de Papeles Sueltos, Primera Serie, de la Biblioteca Dr. Eusebio Dávalos, del Instituto Nacional de Antropología e Historia, documentación que ha sido reclasificada, al momento de la entrega de este artículo permanecía inaccesible dado que dicho recinto se encontraba en reparación.

${ }^{60} \mathrm{El}$ retrato pertenece a una colección particular, y fue subastado por la casa Morton el 27 de enero del 2004; actualmente, una imagen digital de él se encuentra en la plataforma LatinAmericanArt, la cual reúne información relativa al arte latinoamericano. Agradezco la información a Laura Cunningham, colaboradora de dicha plataforma.

${ }^{61}$ Bustamante, Apuntes para la historia..., p. 290.

${ }^{62}$ Malo, Diario de sucesos notables de..., p. 244.

${ }^{63}$ Malo, Diario de sucesos notables de..., p. 251. 
ficarlos por sus atributos, pero resulta más difícil, con los elementos que hay a la mano, argumentar que es su fisonomía la que aparece en la imagen; a ello se aúna el hecho de que es mayor el esquematismo en los rostros de los personajes que los representan a ambos. El que aparece de perfil (lámina 7) hace las veces de Antonio Haro y Tamariz; de este connotado personaje contamos con una amplia biografía escrita por Jan Bazant, ${ }^{64}$ con los testimonios personales de Guillermo Prieto ${ }^{65}$ y Fanny Calderón de la Barca, ${ }^{66}$ y algunos retratos ya publicados; ${ }^{67}$ de éstos, el que resulta más pertinente para ser cotejado con la imagen de El Gallo Pitagórico es un óleo en miniatura pintado en 1831 por un pintor de apellido Bonfigli que lo muestra joven, ${ }^{68}$ pero lo único que se puede afirmar es que al menos no hay rasgos que discrepen entre ambas imágenes, es decir, que dentro del esquematismo y falta de caracterización del supuesto rostro de Haro en la litografía de Faetón, hay algunas coincidencias fisonómicas, aunque demasiado generales: rostro joven, alargado y sin barba, y también larga nariz. Asimismo, poco puede decirse del rostro que representa a Manuel Crecencio Rejón, pues aunque existe una biografía larga escrita por Carlos A. Echánove Trujillo, ${ }^{69}$ y algunos otros textos relativos a su obra política, ${ }^{70}$ los retratos que de él se localizaron en esta investigación ${ }^{71}$ lo muestran con

${ }^{64}$ Jan Bazant, Antonio Haro y Tamariz y sus aventuras políticas: 1811-1869, México, El Colegio de México, 1985.

${ }^{65}$ Prieto, Memorias de mis tiempos..., p. 241. De él dice Prieto: "Era don Antonio Haro un hombrecito como de filigrana, pequeño de cuerpo y esmeradamente vestido. Modales adamados, voz meliflua, y a primera vista un tipo de esos que lucen en una Santa Misa o dirigen con acierto unos lanceros. / Educado con los jesuitas, y en la sociedad monástica de Puebla, era ceremonioso y pulcro; pero cuando daba rienda suelta a sus pasiones políticas, era valiente hasta la temeridad, tenaz hasta lograr sus fines, y astuto como un hijo predilecto de Loyola".

${ }^{66}$ Entre otras páginas, véase Calderón de la Barca, La vida en México..., p. 250.

${ }^{67}$ Uno de juventud y otro de madurez avanzada se pueden ver en Bazant, Antonio Haro y Tamariz..., y en Enrique Cárdenas de la Peña, Mil personajes en el México del siglo XIX: 18401870, México, Banco Mexicano Somex, 1979, v. III, p. 189.

${ }^{68}$ Se reproduce en Bazant, Antonio Haro y Tamariz..., y al pie se especifica el año en que se pintó, aclarándose que se trata de una miniatura al óleo pintada por el citado artista, conservada en el archivo del licenciado Francisco Pérez de Salazar, "hoy de la señora Carmen Pérez Salazar de Ovando y del Lic. Carlos de Ovando".

${ }^{69}$ Echánove, La vida pasional e inquieta..., p. 479.

${ }^{70}$ Daniel Moreno (introd., selec. y notas), Manuel Crecencio Rejón: pensamiento político, México, Secretaría de Educación Pública, 1986 (Cien de México), y Josefina Zoraida Vázquez (comp. e introd.), Manuel Crecencio Rejón, México, Senado de la República, 1987.

${ }^{71}$ Uno de ellos se reproduce en Vázquez (comp. e introd.), Manuel Crecencio Rejón..., p. 33 , sin que se indique su fecha, autor ni procedencia, y el otro, que parece derivado del 


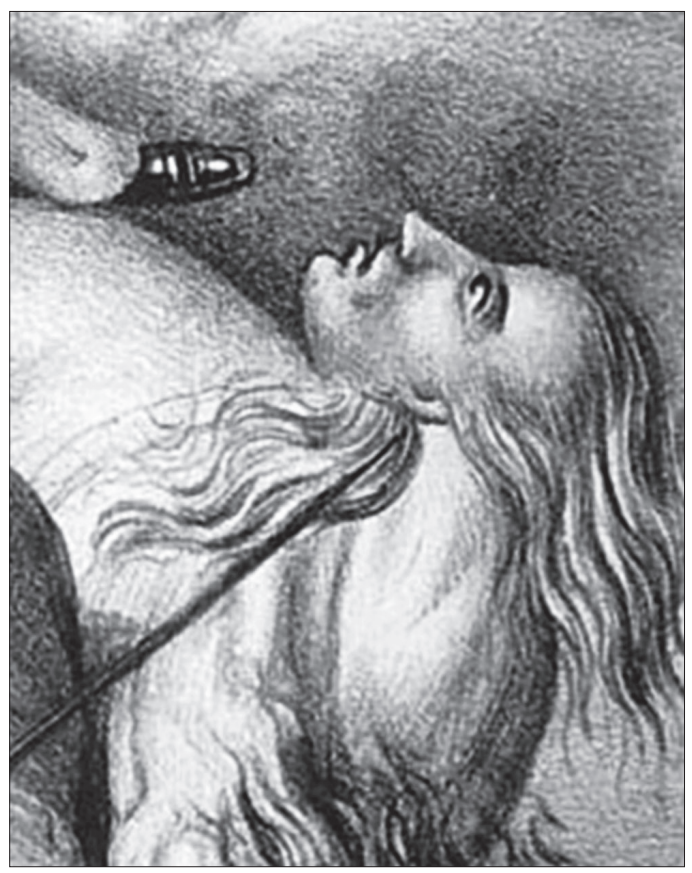

Lámina 7. Litografía de Plácido Blanco, Que Júpiter con sus rayos los arrojara de cabeza al lago de Texcoco, ilustración interior de El Gallo Pitagórico, 1845, detalle

una barba cerrada y muy larga, a diferencia del que aparece en la imagen de El Gallo Pitagórico (cotéjese la lámina 8); no obstante, todos ellos muestran un rostro alargado, una frente amplia y una nariz regular.

A pesar de que a la distancia no todos los rostros son identificables, hay un testimonio que confirma que los contemporáneos efectivamente debieron reconocer en los semblantes de los caballos de la imagen de Faetón los de los defenestrados exministros a quienes, vale la pena reiterarlo, muchos habían visto hablar y defender a Santa Anna en la tribuna; se trata de un comentario que apareció años más tarde, en 1856, en el periódico El Ómnibus, en el que se decía que Morales, apegándose a la regla que, en el arte de las caricaturas, obliga a que se represente al sujeto de manera que no se confunda con otro, había dado en su libro: "el retrato de los cuatro ministros del Sr. Canalizo [como presidente interino], el suyo propio y el del quizá sea una reinterpretación moderna. 


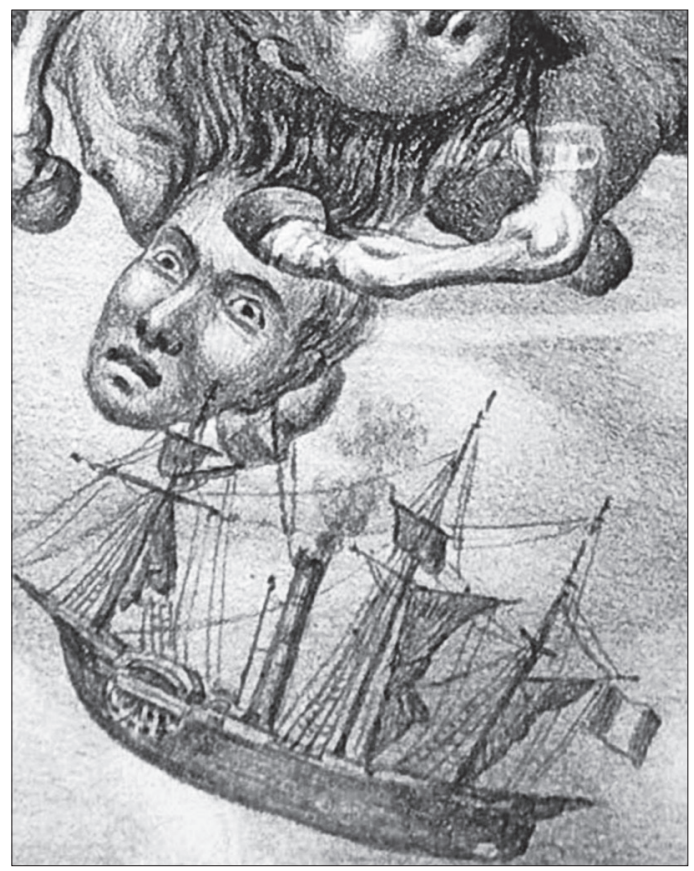

Lámina 8. Litografía de Plácido Blanco, Que Júpiter con sus rayos los arrojara de cabeza al lago de Texcoco, ilustración interior de El Gallo Pitagórico, 1845, detalle

Sr. Cumplido. Cualesquiera que haya conocido á esos caballeros al ver la caricatura que los representa podrán decir señalándolos con el dedo: aquel es Fulano, este es Zutano". ${ }^{72}$

Sobre la actuación de Antonio Haro y el Congreso, cabe decir que a fines de octubre de 1844 había reemplazado a Ignacio Trigueros en el Ministerio de Hacienda, y que las contradicciones entre él y el ministro Baranda enfrente de las Cámaras los habían hecho objeto de las pullas del público $;^{73}$ respecto de su actitud ante el legislativo, el diputado Carlos María de Bustamante comentó que en principio Haro era el único grato a la Cámara porque había sido uno de sus diputados antes de asumir el ministerio, pero que aquélla en realidad

72 "El señor Dr. Juan Bautista Morales defendido ante la opinion pública por los editores del Omnibus. Artículo II”, El Ómnibus, México, 12 de abril de 1856, p. 2. Morales y Cumplido en todo caso aparecieron en otras imágenes de El Gallo Pitagórico, no en la que ahora se analiza.

${ }^{73}$ Bustamante, Apuntes para la historia..., p. 308 y 309. 
no conocia el veneno que ocultaba con una carita humilde é hipócrita, y que despues desarrolló no solo acompañando á Santa-Anna en la campaña é insuflándolo para que causase males, sino lo que es mas, dirigiendo en persona al ejército mostrándole los puntos por donde podia atacar á Puebla su misma patria, y donde vió la primera luz; cosa que horroriza y que no puedo escribir sin pena. ${ }^{74}$

Morales en el texto de El Gallo Pitagórico acusó a Haro de haber "ido á engañar á los gallos representantes, mientras que se acababa de formar un mónstruo terrible que apareció el 29 de Noviembre pasado, y que á no ser porque la Providencia Divina los protegió de un modo maravilloso, se los hubiera tragado indefectiblemente". ${ }^{75}$

De Manuel Crecencio Rejón (al igual que había hecho respecto de los exministros de Justicia y de Guerra), Juan Bautista Morales habló más duramente, afirmando que había puesto "la suprema felicidad en pasar en este mundo la vita bona", y que había sido un bajo adulador de Santa Anna ${ }^{76}$ (por el contrario, Bustamante escribió que Rejón era un "joven de gran talento, pero fatídico, pues en cuantas revoluciones se ha metido ha salido mal, y en esta última peor"). ${ }^{77}$

Desde el momento en que Rejón llegó al Ministerio de Relaciones, tres meses y medio antes del movimiento decembrista, junto con el resto de los ministros y con Canalizo, el presidente sustituto, había enfrentado al Congreso. Su participación en el gabinete fue influyente y activa, no sólo porque a él le correspondía el manejo de lo relacionado con la álgida relación entre México, Texas y Estados Unidos (en este asunto, favoreció desde luego la postura bélica de Santa Anna), sino porque, según su propio testimonio, fue él mismo quien en junta de ministros aconsejó que se impidiera, "por algún tiempo", el ejercicio de funciones del legislativo (además, reconoció que desde tres meses atrás, había aconsejado al jefe de la administración dicha medida, que supuestamente aquél rechazó); luego él, Basadre y Canalizo, y

${ }^{74}$ Bustamante, Apuntes para la historia..., p. 352.

${ }^{75}$ Morales, El Gallo Pitagórico (1845), p. 266.

${ }^{76}$ Morales, El Gallo Pitagórico (1845), p. 266.

77 Bustamante, Apuntes para la historia..., p. 294. Cabe preguntarse si quizá habrá sido el propio intelectual e historiador quien defendió infructuosamente a Rejón ante el Tribunal Supremo de Justicia, pues se tiene noticia de que un diputado de apellido Bustamante fue quien lo hizo; Echánove, La vida pasional e inquieta..., p. 349. Al respecto, conviene recordar que fue Bustamante quien años atrás defendió a Lucas Alamán en el juicio por la muerte de Guerrero. 
otros militares expidieron el decreto del 29 de noviembre, y otro más para restringir la libertad de imprenta. ${ }^{78}$ Tiempo después, en 1846, desde el destierro, Rejón publicó un folleto con una larga justificación de su proceder como ministro y, sobre todo, del porqué de su decisión de disolver al legislativo $;^{79}$ en ella, señaló que la conducta de los legisladores y las "especies" que hacían circular sus "parciales” demostraban que su proyecto era derribar a la administración y reemplazarla con otra que dirigieran sus hombres importantes, y para consolidarla, sacrificarían inicuamente una parte del territorio nacional, pues estando a punto de desmembrarse éste, el Congreso, en vez de auxiliar al gobierno, lo atacaba, por lo que se había "constituido" uno de esos raros y terribles casos "en que se autoriza el silencio de las leyes". ${ }^{80}$ Según Echánove, su biógrafo, fueron finalmente las disposiciones de Rejón las que hicieron caer al gobierno de Santa Anna, y con ellas, consumó de propia mano su desprestigio.

El Gallo Pitagórico y una imagen como ésta del Faetón, seguramente contribuyeron con su grano de arena a alimentar dicho desprestigio ante la opinión pública. De hecho, la condena a los ministros por la expedición del decreto del 29 de noviembre se muestra en otras dos caricaturas publicadas en la época: en una de las escenas de la que se titula Ensueño del tirano, en donde los supuestos ministros conspiran y hollan las leyes al pisotear el libro en que éstas se compendian (el que va vestido de militar debe representar a Basadre) y en un detalle de Sainete político, donde un gato, que se encuentra boca arriba y lleva una banda (quizá para representar el cargo de los ministros), sostiene un papel que alude explícitamente a dicha medida. ${ }^{81}$

Identidad elusiva: ¿dos Faetones?

Hasta aquí las evidencias. No hay duda de que quienes en la imagen están representados en los caballos del caído carro del sol, o sea el carro del

${ }^{78}$ Echánove, La vida pasional e inquieta..., p. 345-346.

${ }^{79}$ El texto de Rejón se publicó en Nueva Orleáns en enero de 1846, véase Moreno, Manuel Crecencio Rejón..., p. 41-78. Su título se consigna en la parte del texto que en el presente artículo corresponde a la nota 85.

${ }^{80}$ Echánove, La vida pasional e inquieta..., p. 341.

${ }^{81}$ Ambas imágenes se reproducen en Barajas Durán (el Fisgón), Historia de un país en caricatura..., p. 140-141 y 144-145. 
Estado, son los cuatro últimos ministros santannistas en 1844. Todos ellos, junto con Santa Anna y Canalizo, fueron acusados de haber atacado el sistema constitucional establecido en las Bases Orgánicas, con la expedición del decreto del 29 de noviembre, y por ello, los legisladores iniciaron los trámites ante el Gran Jurado de las Cámaras para que se les promoviera proceso judicial. ${ }^{82}$

Hablemos ahora de las ambigüedades. La primera es que el derribado Faetón a los ojos de los contemporáneos parece haber representado a dos distintos personajes públicos (aunque en última instancia se refiriera sólo a uno), y la otra es que nuevamente, como lo hizo en el propio texto de $E l$ Gallo Pitagórico, Morales eludió adjudicarle al Congreso la victoria sobre el ejecutivo santannista. En cuanto a la primera ambigüedad, es decir, a la identidad de Faetón, la imagen de El Gallo Pitagórico es deliberadamente elusiva, pues mientras que en el dibujo de Miguel Ángel, del cual ésta derivó, el hijo del Sol tiene la cara descubierta (lámina 9, detalle), en aquélla el dibujante puso uno de los brazos sobre el rostro del conductor, evitando con esto mostrarlo explícitamente; otro detalle, que por el contrario ya existía en el dibujo de Miguel Ángel y que se siguió a la hora de dibujar la imagen de El Gallo Pitagórico, era que convenientemente se ocultaba uno de los pies de la susodicha figura; con ello, se evitó también mostrar la pata de palo de Santa Anna que lo hacía plenamente identificable. Interesa señalar que quien hizo el diseño, o quien lo dirigió, debió tener consciencia de que a la hora de adaptar la figura y luego imprimirla, ésta quedaría invertida, y en vez de que fuera la pierna derecha la que quedara escondida - como se ve en el dibujo del genial artista italiano-, sería la izquierda la que aparecería cubierta por algún elemento del desbaratado carro. Deliberadamente o no, así se consiguió una velada alusión a la pierna amputada de Santa Anna, que era justamente la izquierda ${ }^{83}$ (véase la

${ }^{82}$ En relación con Santa Anna, el jurado lo acusó ante las dos cámaras, el 24 de febrero de 1845, de violar la ley fundamental, atacar las formas republicanas adoptadas por la nación, y faltar a los juramentos que había prestado; Bustamante, Apuntes para la historia..., p. 435. Declarado culpable, su causa pasó a la Suprema Corte, a la que correspondía seguirla y dictar sentencia.

${ }^{83}$ Respecto de que fue la pierna izquierda la que le fue amputada a Santa Anna tras su enfrentamiento con los franceses en diciembre de 1838, véase el parte de guerra que el mismo general hizo respecto de los sucesos el 13 de diciembre de 1838; Boletín Oficial, México, s. f., Imprenta del Águila, 1838. Este documento se encuentra inserto en Bustamante, Diario histórico de México..., CD 2, véanse anexos, diciembre de 1838. 


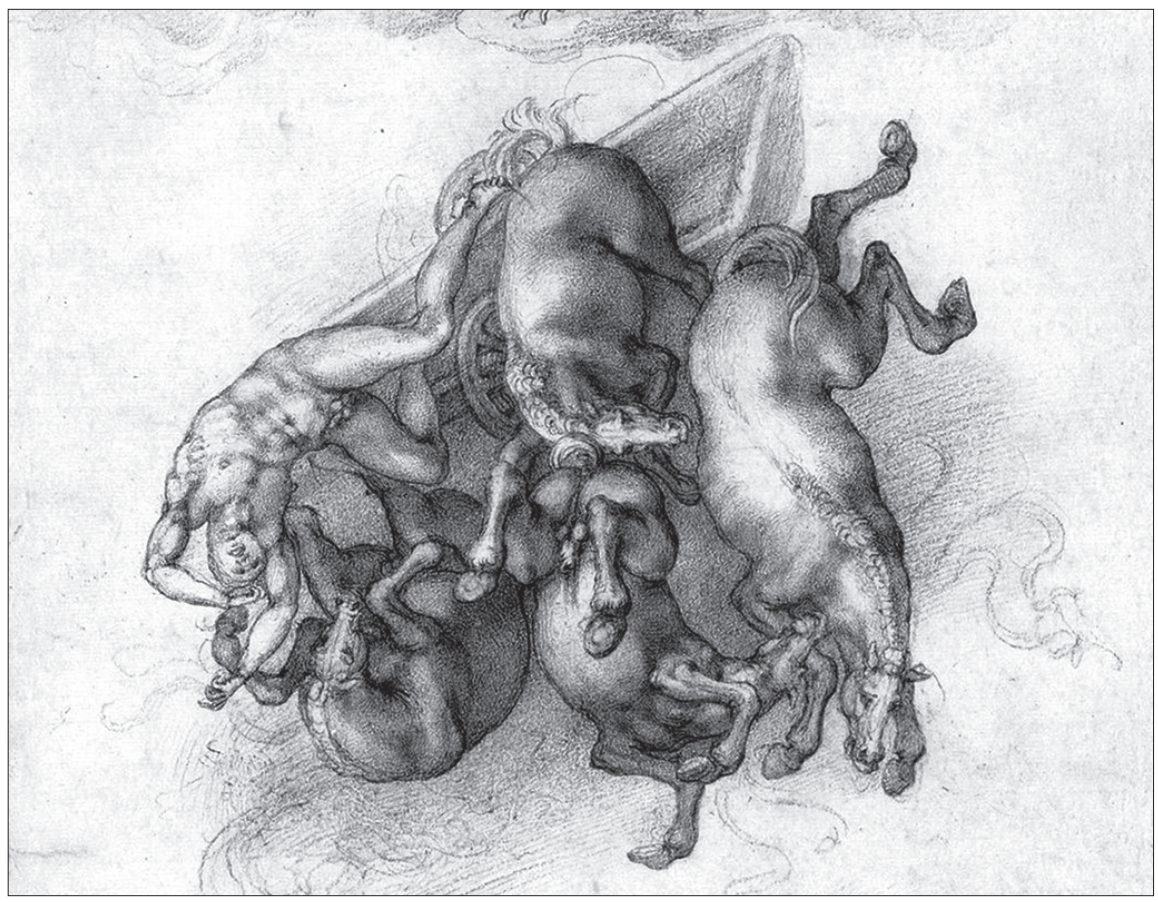

Lámina 9. Dibujo de Miguel Ángel, La caída de Faetón, 1533, detalle

lámina 10, en donde se muestra este detalle de la imagen, pero invertido, es decir, tal como el dibujante lo trazó sobre la piedra litográfica, y que al imprimirse quedó al revés; si además se coteja con la lámina 2, se apreciará el resultado final, luego de la impresión).

Por otra parte, a diferencia del desnudo Faetón del original, el de la imagen de El Gallo Pitagórico, dada su vestimenta, es un militar, aunque no lleve charreteras. Que en la figura se representa al caudillo se infiere no sólo por ser él el encargado en última instancia de dirigir "el carro del Estado", sino porque a su espalda se ve un respaldo que debe simbolizar la silla presidencial (en años posteriores, éste sería un tópico para representar al poder presidencial en las caricaturas). En cuanto a que en el Faetón se podía estar representando a la vez a dos personas, o en todo caso, que sus contemporáneos pudieron haberle asignado a dicho personaje dos personalidades distintas, hay que recordar que desde septiembre de 1844 el general Valentín Canalizo había asumido la presidencia interina, y que, como se ha reiterado, fueron él y los ministros quienes expidieron y trataron de imponer el bando que pretendía disolver al Congreso (probablemente 


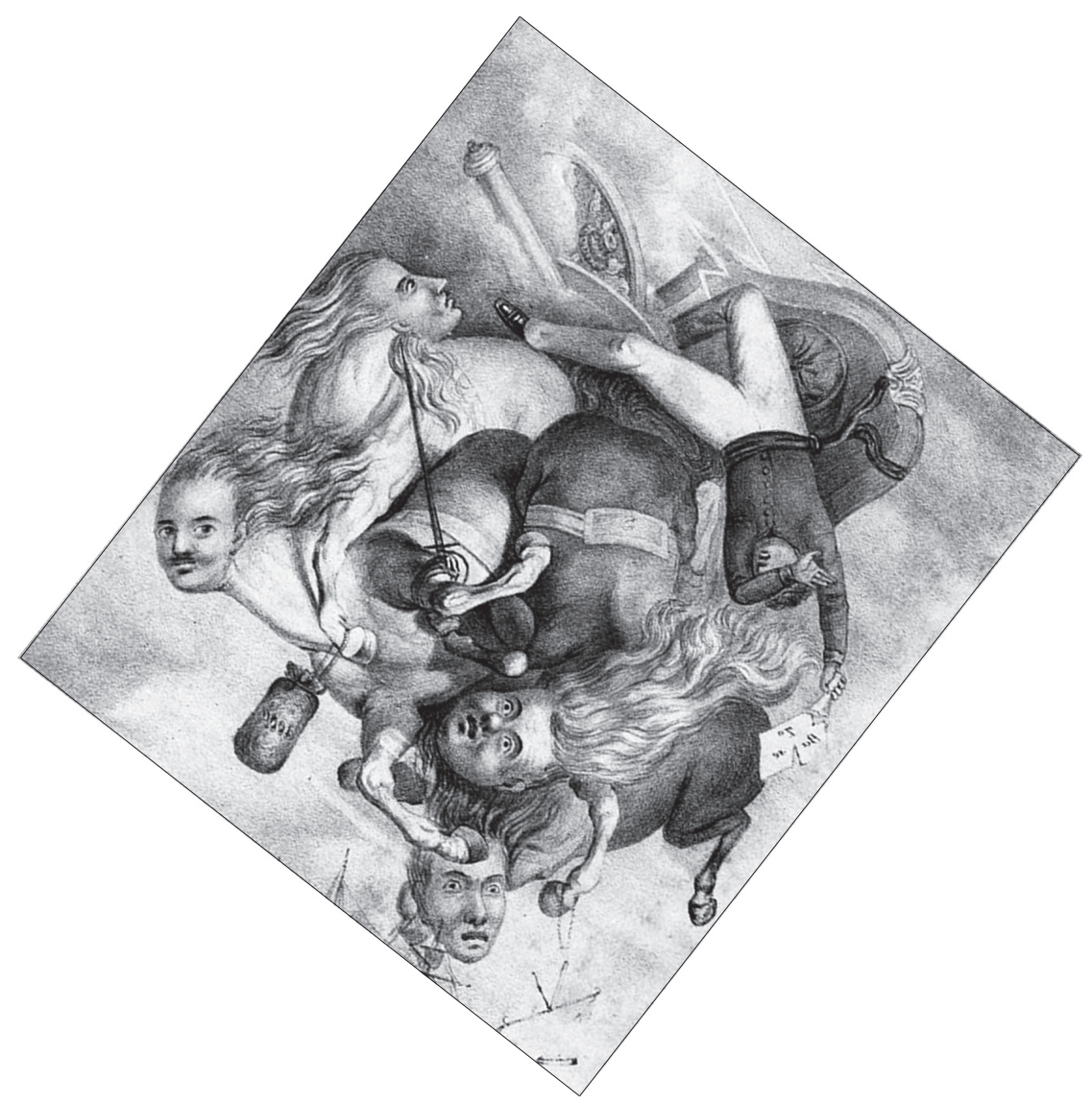

Lámina 10. Detalle invertido y además virado de posición, de la litografía de Plácido Blanco, Que Júpiter con sus rayos los arrojara de cabeza al lago de Texcoco, ilustración interior de El Gallo Pitagórico, 1845

instigados por Santa Anna). De hecho, Canalizo era quien legalmente llevaba las riendas del gobierno cuando estalló el movimiento decembrista, y fue él quien, luego de pretender volar Palacio Nacional, concertó con José Joaquín Herrera la rendición y la entrega del poder.

Sin que ello se oponga al hecho de que en realidad era Santa Anna quien gobernaba a distancia, hay algunos documentos y varios comentarios vertidos en la época, o años después, que ponen de manifiesto que pudo percibirse a Canalizo como el director del Estado al momento de la debacle santannista. Uno de esos comentarios, por ejemplo, fue emitido por La Voz de Michoacán a mediados de junio de 1845 - tan sólo un mes después 
de que se publicó El Gallo Pitagórico-, en el que, refiriéndose a la deseable candidatura de Herrera en las próximas elecciones, se decía: "el virtuoso republicano que se puso á su frente el glorioso 6 de Diciembre último para derrocar el funesto despotismo de la administracion del general Canalizo". ${ }^{84}$ Otro documento en el que se asienta la misma idea fue el citado folleto publicado en enero de 1846 en Nueva Orleáns, y escrito por uno de los ministros para justificar sus acciones, y cuyo extenso título es Justificación eco de la conducta de Manuel Crecencio Rejón, desde octubre de 1841 hasta la fecha, y especialmente de los decretos de 29 de noviembre y 2 de diciembre de 1844 que autorizó como ministro de Relaciones Exteriores y Gobernación en el último gobierno del excelentísimo señor don Valentín Canalizo. ${ }^{85} \mathrm{La}$ idea también se manifestó en un párrafo citado más atrás, y publicado en 1855, en el que además se hacía referencia directa a la imagen de Faetón; conviene repetir una parte de lo que éste decía respecto de El Gallo Pitagórico: "en esa produccion de circunstancias [Morales] quiso dar el retrato de los cuatro ministros del Sr. Canalizo" ${ }^{86}$ Por lo tanto, pareciera que la coyuntura ayudaba al autor de El Gallo Pitagórico para no ser tan directo, pues, como se ha dicho, se mostraba precavido ante la aún fuerte influencia de Santa Anna. De hecho, aunque la fisonomía de Canalizo tampoco apareció en ninguna de las estampas del libro de Morales, en el texto sí se criticó el papel que tuvo como expresidente interino en el intento de disolver al Congreso. ${ }^{87}$

Por otra parte, en la mano del Faetón de El Gallo Pitagórico hay un papel que dice 7a. Base - o sea, la séptima de las Bases de Tacubaya-, y que está roto para simbolizar su final extinción y fracaso al caer la administración de Santa Anna. Dicha base era la que en 1841 le concedió facultades extraordinarias al general con el fin de que reorganizara la administración pública, y literalmente decía: "Las facultades del Ejecutivo provisional son todas las necesarias para la organización de todos los ramos

${ }^{84}$ El artículo, publicado el 22 de junio, fue reproducido en El Siglo Diez y Nueve; "Postulacion para la presidencia de la república”, El Siglo Diez y Nueve, México, 27 de junio de 1845 , p. 4.

${ }^{85}$ Cabe la sospecha de que por su parte Rejón, y tal vez sus compañeros santannistas, para desviar las culpas de su líder en el fracaso de 1844, haya decidido señalar en el título de su documento que quien gobernaba era Canalizo. El texto de Rejón, publicado en Nueva Orleáns en enero de 1846, se reproduce en Moreno, Manuel Crecencio Rejón..., p. 41-78.

86 "El señor Dr. Juan Bautista Morales: Defendido ante la opinion pública por los editores del Omnibus. Artículo II”, El Ómnibus, México, 12 de abril de 1856, p. 2.

${ }^{87}$ Morales, El Gallo Pitagórico (1845), p. 262-263. 
de la Administración pública”. ${ }^{88}$ Respecto de esto, Morales opinaba que el caudillo había descuidado esa responsabilidad por su interés exclusivo de atender al ejército, y que en el fondo había utilizado de forma arbitraria sus facultades para enriquecerse y dejar que se enriquecieran algunos otros. ${ }^{89}$ Pero volviendo al punto del cual partimos, el que en la mano del ambiguo Faetón haya una referencia directa a la 7a. Base, indica que en el fondo el personaje al que representa es Santa Anna, lo cual, como quiera, no se contrapone al hecho de que sus contemporáneos hayan podido identificar en dicho personaje también a Canalizo, quien, siendo su sustituto en la presidencia, podría serlo también en la estampa. De cualquier modo, todo mundo sabía que él era un títere de Santa Anna.

¿Quién fue el Júpiter que fulminó el carro de Santa Anna-Faetón, o de quién fue la victoria?

Sin embargo, el punto más ambiguo es el que se muestra en la parte superior de la imagen, es decir, el que se refiere a la identidad del Júpiter que lanza sus rayos para terminar de destruir el alegórico carro y detener su desbocada carrera; aquí es donde el autor de El Gallo Pitagórico habla del triunfo sobre Santa Anna. Sabemos que éste se debió al Congreso, y que entre los moderados que lo controlaban, además de Manuel Gómez Pedraza (el líder del grupo por muchos años), estaba el propio Juan Bautista Morales, a quien se ha calificado como uno de los más importantes líderes del movimiento del 6 de Diciembre de $1844 .{ }^{90}$ Sin embargo, el propio Morales siempre eludió hablar de esa victoria de forma explícita cuando se expresó públicamente

${ }^{88}$ Citada en Olavarría y Ferrari, México independiente..., t. viII, p. 33.

${ }^{89}$ Morales aludió al enriquecimiento de Santa Anna al referirse a él bajo el mote de Tripas de oro en El Gallo Pitagórico. Además, en un artículo que publicó sin firma en 1842 y que lo llevó a la cárcel, culpó explícitamente al gobierno del general de desatender la crisis económica del país y la administración pública, y ocuparse sólo en fortalecer al ejército para reconquistar Texas, asunto que para muchos de sus contemporáneos era un pretexto que permitía obtener jugosas ganancias a Santa Anna y allegados (especuladores y fabricantes de equipo militar), y que, aunque no fue mencionado por Morales, subyacía en su artículo. De acuerdo con el embajador británico - quien lo escribió en una carta privada-, el mismo Santa Anna tenía "sin la menor duda, un gran interés personal" en ello, es decir, un interés económico. Cfr. "Reorganizacion”, El Siglo Diez y Nueve, México, 4 de julio de 1842, p. 3-4, y "Concluye el artículo sobre regeneracion [sic, reorganización]", ibidem, n. 269, 5 de julio de 1842, p. 3 y 4, con la carta citada por Costeloe, La república central en México..., p. 314.

${ }^{90}$ Santoni, Mexican at Arms..., p. 23, 48 y 49. 
sobre estos hechos, o sea en las dos ediciones de El Gallo Pitagórico, de $1845^{91}$ y 1857 , y en la citada carta suya que se difundió en El Siglo Diez y Nueve en abril de 1845; en ésta expresó el siguiente pensamiento: "quien es el que niega que su caida ha estado fuera del alcance de los esfuerzos de los hombres, y aun de la prevision, y que aquella no reconoce otro agente que una especial proteccion de la Providencia!"92 Sólo en privado, en una carta que a fines de 1845 envió al general Paredes, Morales llegó a mencionar la responsabilidad del movimiento decembrista y de él mismo en el desaplazamiento de Santa Anna. ${ }^{93}$

Respecto de lo anterior, en esta imagen Morales no hizo la excepción, pues al menos a los ojos actuales no son muchas las pistas que a primera vista puedan ayudar a saber a quién está representando el esquemático Júpiter. De seguro no simboliza al Congreso, pues su atuendo también es el de un militar (aunque tampoco lleva charreteras). Podría aducirse que se trata de Mariano Paredes, pero resulta dudoso porque a pesar de que su pronunciamiento en Jalisco fue el que dio impulso al movimiento decembrista de 1844, su ayuda, aunque importante, terminó siendo tangencial. Por otra parte, la relación entre el partido de Morales y este importante y ambicioso jefe militar fue más bien tensa y llena de desconfianzas, y de hecho, al final él fue quien los desplazó y sustituyó en el poder. ${ }^{94}$

Lo más probable es que en el Júpiter de la estampa se esté representando a José Joaquín de Herrera, quien a la caída de Santa Anna fue designado presidente interino, y al poco tiempo confirmado en el cargo, luego de las elecciones realizadas en agosto de 1845 . Así podría interpretarse a la luz del comentario citado líneas atrás que, en vísperas de las elecciones, emitió La Voz de Michoacán, y que fue recogido por El Siglo Diez y Nueve, en el cual se afirmaba que Herrera había sido "el virtuoso republicano que

${ }^{91}$ Más atrás se señaló ya que en la edición de 1845 Morales afirmó respecto de los legisladores "que á no ser porque la Providencia Divina los protegió de un modo maravilloso", el monstruo encarnado en el decreto del 29 de noviembre "se los hubiera tragado indefectiblemente”; Morales, El Gallo Pitagórico (1845), p. 266.

${ }^{92}$ Juan Bautista Morales, "Ministerio de Relaciones Exteriores, Gobernacion y Policia", El Siglo Diez y Nueve, México, 22 de abril de 1845, p. 1.

${ }^{93}$ En ella afirmó: "Nuestra conducta debe ser la que manifestamos desde el día 6 de diciembre todos los que poco o mucho, según nuestras facultades y posición, contribuímos a derrocar el despotismo entronizado hasta entonces... No hay armas con que mejor se contraste la mentira, que la verdad"; la carta fue escrita el 10 de septiembre de 1845 , y es citada en Rodríguez Frausto, “Juan Bautista Morales: abogado, político...”, n. 35, s. n. p.

${ }^{94}$ Santoni, Mexican at Arms..., p. 22. 
se puso á su frente [de la nación] el glorioso 6 de Diciembre último para derrocar el funesto despotismo de la administracion del general Canalizo". Había sido efectivamente Herrera quien, en la capital, se había puesto a la cabeza de las tropas que desertaron del gobierno de Santa Anna para apoyar el movimiento decembrista, y quien, junto con los diputados, invitó a Canalizo a rendirse - tal vez por esto el personaje levanta en alto un amenazante sable-; luego de conseguir su objetivo se instauró un nuevo orden de cosas. Además, Herrera fue el elegido por el senado para fungir como presidente interino mientras la nación se reorganizaba y se preparaban las elecciones; fue también quien instó a Santa Anna a deponer las armas y quien enfrentó a su vez las amenazas que éste lanzó sobre la ciudad de México. ${ }^{95} \mathrm{El}$ hecho de que sea Herrera a quien se representa como el gran triunfador sobre el caudillo indicaría que El Gallo Pitagórico en buena medida se publicó para defender al gobierno herrerista de la campaña de impugnaciones emprendida en su contra tanto por los liberales radicales como por los santannistas, ${ }^{96}$ es decir, para favorecer al gobierno moderado al que pertenecían Juan Bautista Morales e Ignacio Cumplido ya en los primeros meses de 1845 .

Por otra parte, en lo que se refiere a la propia imagen, aunque apenas perceptible, dado su diminuto tamaño y relativo esquematismo, hay en el peculiar Júpiter algunos rasgos muy característicos que se muestran en los retratos de Herrera (láminas 11 -detalle - y 12): la grande patilla blanca, y el cabello peinado hacia adelante, con un flequillo acomodado en picos y pegado sobre la frente. Dicho personaje, y el águila que monta, esgrimen las leyes que Santa Anna había violentado, por lo que es necesario señalar aunque sea escuetamente algo sobre el simbolismo propio de estas figuras mitológicas, y en seguida algo más sobre la esencia de los reclamos que, al enunciar dichas leyes, se le hacían al expresidente mexicano. Júpiter, dios romano equivalente al Zeus griego, como padre de los dioses del Olimpo fue emblema recurrente en la simbología utilizada en torno a la realeza europea a lo largo de los siglos. A menudo se le asocian el águila y el rayo; este último simboliza "el poder, soberanía y rapidez en la ejecución de la justicia”. Ya desde los poemas homéricos el papel del dios "fue el de poner orden y justicia en el mundo y de castigar con su

${ }^{95}$ Costeloe, La república central en México..., p. 326. Desafortunadamente, no da mayor información al respecto.

${ }^{96}$ Santoni, Mexican at Arms..., p. 74-82. 


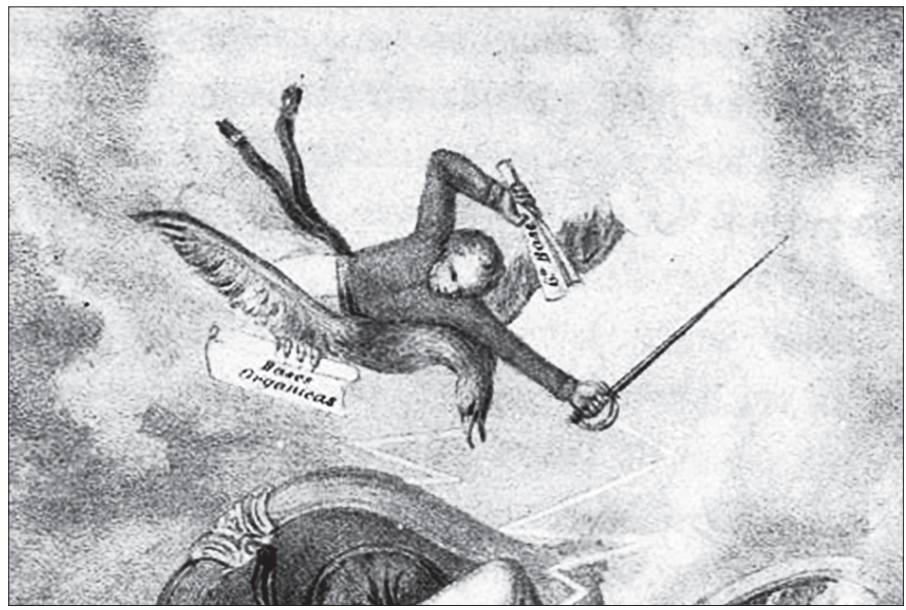

Lámina 11. Litografía de Plácido Blanco, Que Júpiter con sus rayos los arrojara de cabeza al lago de Texcoco, ilustración interior de El Gallo Pitagórico, 1845, detalle

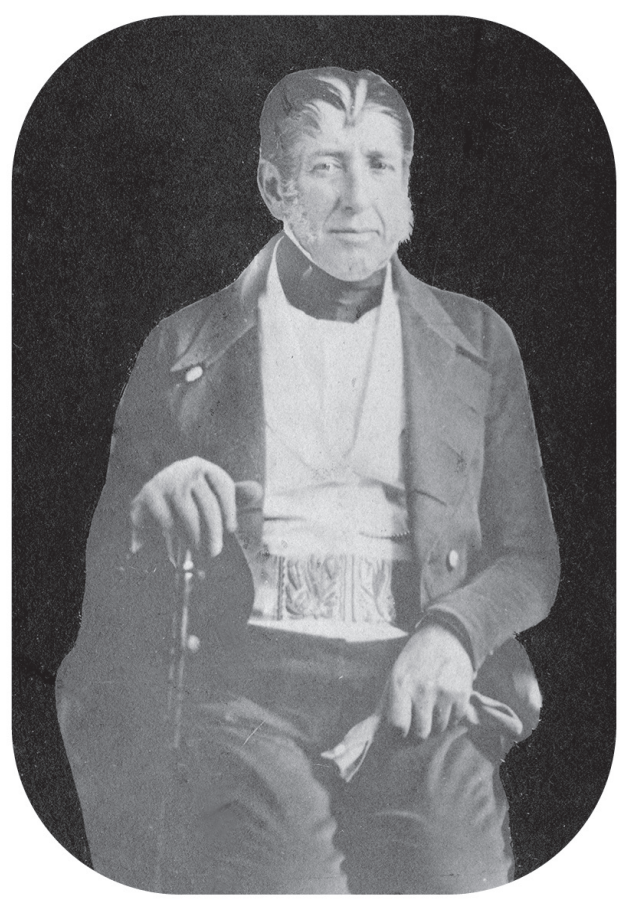

Lámina 12. Fotografía de José Joaquín de Herrera, Retratos mexicanos, Biblioteca Nacional de México, Fondo José María Lafragua 
rayo a los que no obedecían su mandato. Cuando el dios quiso entrar en contacto con los mortales, el águila fue su mensajera"; ${ }^{97}$ respecto de ésta, resulta interesante recordar las cualidades que, en su interconexión con Zeus y como administradora de la justicia del dios, se le adjudicaron en Empresas políticas, un conocido libro de emblemas publicado en 1640 y dedicado a la educación del malogrado hijo de Felipe IV: la agudeza de vista "para inquirir los delitos, la ligereza de sus alas para la ejecución; la fortaleza de sus garras, para no aflojar en ella". ${ }^{9}$

En vista de lo anterior, queda claro que el papel de Júpiter-Herrera y su águila es el de hacer justicia respecto de las supuestas transgresiones cometidas por la administración de Santa Anna; ¿̇cuáles fueron los principales reclamos que en la imagen se le lanzaron al caído expresidente, además de haber abusado del poder que se le había concedido en vez de arreglar la administración pública? Uno concierne indiscutiblemente a la disolución del Congreso de 1842, pues está implícito en la enunciación de la 6a. Base de Tacubaya (emitida junto con las otras, en 1841), y que se plasma en el papel que Júpiter lleva en la mano, dado que en ella se establecía que el ejecutivo provisional respondería de sus actos ante el Primer Congreso Constitucional, ${ }^{99}$ y como sabemos, Santa Anna simple y llanamente lo disolvió. La otra gran transgresión se invoca en la inscripción del papel que lleva el águila, que reza "Bases Orgánicas", y fue precisamente la cometida en dichas bases -emitidas en 1843 por la Junta de Notables designada por el propio general-, al trastocar el orden legal y el propio sistema republicano cuando intentó disolver el Congreso de 1844 (mediante el decreto del 29 de noviembre) y depuso al gobernador y a la asamblea departamental de Querétaro. En efecto, la misma noche del 6 de diciembre el Gran Jurado de las Cámaras había acusado a Santa Anna de atacar el sistema constitucional establecido precisamente en dichas Bases. ${ }^{100}$ Por lo tanto en este punto Morales argüía la legitimidad de dicha Constitución de sesgo centralista,

97 Nelly Sigaut, “El uso de la emblemática en un programa catedralicio”, en Herón Pérez Martínez y Bárbara Skinfill Nogal (eds.), Esplendor y ocaso de la cultura simbólica, Zamora, El Colegio de Michoacán/Consejo Nacional para la Ciencia y la Tecnología, 2002, p. 128.

${ }^{98}$ El libro fue escrito por Diego Saavedra Fajardo, y el fragmento citado aparece en Jesús María González de Zárate, “Imagen y poder, alegorías en emblemas”, en Rafael Zafra y José Javier Azanza (eds.), Emblemata Aurea: la emblemática en el arte y la literatura del Siglo de Oro, Madrid, Akal, 2000, p. 229.

${ }^{99}$ Olavarría y Ferrari, México independiente..., t. viıI, p. 33.

100 Véanse los términos de la acusación que le hicieron los diputados Manuel Alas y José Llaca, en Bustamante, Apuntes para la historia..., p. 421 y 422. 
la cual fue defendida a lo largo de 1845 por él y su grupo, a pesar de que se contraponía con sus añejas convicciones federalistas y, por lo tanto, con lo que había propugnado en años anteriores.

En relación con este último punto, conviene comentar de forma sucinta una cuestión. En dos de sus artículos de El Gallo Pitagórico publicados uno en 1842 y otro en 1843, Morales había expresado justamente su posición federalista, ${ }^{101}$ aunque para 1844 , en otro de esos artículos, manifestó por el contrario, la necesidad de apegarse al orden — centralista- establecido por las Bases Orgánicas. ${ }^{102}$ Tras la contradicción había evidentemente un pragmatismo político que el propio Morales había justificado en la citada carta que hizo aparecer en El Siglo Diez y Nueve en abril de 1845. Por lo tanto, el hecho de colocar dichas Bases en las garras del águila que monta el Júpiter de la estampa también pone en evidencia el apoyo que, en 1845, le daban el autor de El Gallo Pitagórico y su grupo político a dicha Constitución y, por ende, a los cambios de opinión de que, en distintas ocasiones, fueron acusados los moderados. ${ }^{103}$

Por último, valdría la pena recoger un dato meramente anecdótico para destacar una curiosa coincidencia entre los hechos que se verificaron en 1845 y el deseo que Morales expresó veladamente en 1843 en el artículo de El Gallo Pitagórico que la imagen ilustró, y que se plasmó luego sintéticamente en el título de ésta, respecto de que sería bueno que "todos los gobernantes ineptos” corrieran la suerte de Faetón: “iQué Júpiter con sus rayos los arrojara de cabeza al caudaloso Eridano, ó aunque fuera al lago de Texcoco!" 104 De acuerdo con Bustamante, cuando a fines de diciembre de 1844 Santa Anna intentó iniciar su acoso a la ciudad de México, se rumoró que había ordenado que se le diera casa en Guadalupe, por lo que se creyó que establecería ahí su cuartel general, pero no fue así, sino que marchó para Texcoco, hospedándose en la casa del exmarqués de Salinas. Se aseguró entonces que el derrocado presidente se había reunido en ese lugar con sus ministros y otras personas, reclamando el que se le hubiese hecho creer que sería apoyado a su regreso a la capital, y que particularmente

${ }^{101}$ Los artículos a los que me refiero fueron publicados en El Siglo Diez y Nueve, uno el 22 de junio de 1842 y otro el 5 de junio de 1843.

102 El que publicó el 21 de septiembre de 1844, también en El Siglo Diez y Nueve.

103 Will Fowler, Mexico in the Age of Proposals, 1821-1853, Westport/Londres, Greenwood Press, 1998, p. 129.

${ }^{104}$ Erasmo Luján, "Remitido/El congreso de los dioses”, El Siglo Diez y Nueve, México, 5 de junio de 1843, p. 1, y Morales, El Gallo Pitagórico (1845), p. 123. 
"dirigió la palabra increpándole á Baranda en razon de las exhortaciones que le habia hecho para que marchase sobre Mexico”. De ahí, Santa Anna marchó hacia Puebla con su ejército, en donde cometería una masacre, pero, gracias a los refuerzos militares enviados por el gobierno de Herrera, terminaría siendo derrotado, perseguido y capturado. ${ }^{105}$ Por lo tanto, el enfrentamiento de los propios miembros del ejecutivo en Texcoco hizo ya evidente el naufragio final de la administración santannista instaurada apenas unos años atrás.

\section{Conclusión}

De lo dicho arriba, está claro que la principal acusación que se hizo al régimen santannista en la imagen de El Gallo Pitagórico aquí estudiada fue la de haber traicionado la confianza que en él había depositado la nación mexicana al concederle facultades extraordinarias en 1841, las cuales desde su perspectiva, en vez de servir a la regeneración del Estado, habrían sido utilizadas por el general en su propio provecho para concentrar el poder y actuar a su antojo; con ello habría trastocado el orden legal, pues en última instancia se le acusó de la disolución del Congreso de 1842 y principalmente de intentar, con ayuda de sus cuatro ministros, hacer lo mismo con el legislativo de 1844. A ambos Congresos habían pertenecido Juan Bautista Morales e Ignacio Cumplido, autor y editor de El Gallo Pitagórico. ${ }^{106}$

Llama mucho la atención el hecho de que mientras la denuncia fundamental en la imagen, seguramente ideada por Morales, es la de los ataques del santannismo en contra del Congreso, en cambio se eluda mostrar en ella el papel protagónico del mismo legislativo en el colapso de la administración del caudillo veracruzano en 1844, y se le asigne todo el crédito del triunfo a un solo personaje: el general José Joaquín Herrera. Esto debió tener un doble objetivo: por una parte dar legitimidad y prestigio a la presidencia moderada del general Herrera, que era el que gobernaba en ese momento y se veía amenazado por los santannistas y sus aliados, y

105 Bustamante, Apuntes para la historia..., p. 389 y 390.

${ }^{106}$ En cuanto a la participación de Morales y Cumplido también como diputados en el Congreso de 1842, véanse respectivamente El Siglo Diez y Nueve, México, 6 de julio de 1842, 270, p. 4, y Cecilia Noriega Elío, El Constituyente de 1842, México, Universidad Nacional Autónoma de México, Instituto de Investigaciones Históricas, 1986, p. 85-87. 
por otra evitar la responsabilidad de asumir un triunfo que en cualquier momento podría revertirse. A esto mismo se debió de seguro el que la crítica a la principal figura del gobierno anterior, o sea Antonio López de Santa Anna, fuera velada.

En efecto, como ya se ha comentado, es muy posible que lo indirecto de los ataques del libro e imágenes de El Gallo Pitagórico se deba al hecho de que, a pesar de que el general veracruzano había sido expulsado de la presidencia, su influencia no había desaparecido, y sus seguidores de inmediato, de manera soterrada, habían empezado a preparar su regreso. No podía asegurarse que el expresidente no recuperaría el poder y volvería al primer plano de la escena política — como efectivamente ocurrió en 1846-, a pesar de los esfuerzos de los liberales moderados por alejarlo. Morales estaba plenamente consciente de ello, y de hecho es muy posible que a eso mismo se deba la existencia misma de El Gallo Pitagórico y sus imágenes: estaban en juego las posiciones que el partido moderado con muchas dificultades había conquistado; en el caso de Morales, ahora gobernador de Guanajuato, incluso el costo fue hacer a un lado sus propias convicciones federalistas y ser cuestionado públicamente por ello. ${ }^{107}$

En cuanto a la imagen propiamente, el análisis ha mostrado que más allá del texto al que acompaña, es ella misma la que enuncia desde lo visual lo que arriba se ha referido: el merecido castigo del ejecutivo santannista por trastornar la legalidad. Es decir, la imagen actuó por sí y aportó los elementos y pistas centrales de su propio argumento, los cuales no se encuentran en el texto que ilustró, con lo que coadyuvó a que El Gallo Pitágorico, que en su mayor parte era una compilación de artículos publicados años atrás, se reactualizara, complementando lo ahí escrito y refiriendo sucesos posteriores y el desenlace que tuvieron. ${ }^{108}$ Está claro, por lo tanto, que para comprender esta obra, debida a un político como Juan Bautista Morales, con una importante participación pública en la época, es necesario revisar asimismo sus imágenes, pues una parte de lo que él esgrimió desde su muy particular punto de vista sobre los hechos históricos se encuentra en ellas.

107 "Remitidos/Exmo. Sr. D. Juan Bautista Morales", El Estandarte Nacional, México, 30 de abril de 1845 , n. 8, p. 3-4.

${ }^{108}$ Esa función también la cubrió el capítulo final del libro, el único escrito ex professo para éste y no publicado con anterioridad en El Siglo Diez y Nueve. De hecho, la imagen, además de ilustrar el artículo en el que se inserta, enlazó también con este último texto, pues los personajes que aparecen caricaturizados en ella son descritos también en él. 


\section{REFERENCIAS BIBLIOGRÁFICAS}

Barajas Durán, Rafael (el Fisgón), Historia de un país en caricatura: Caricatura mexicana de combate, 1821-1972, México, Fondo de Cultura Económica, 2013.

BARRANCO LORENTE, Elisa, El mito de Faetón en ediciones ilustradas de las Metamorfosis de Ovidio (siglos XVI y XVII), trabajo fin de máster en Estudios Avanzados en Patrimonio Cultural: Historia, Arte y Patrimonio, Jaén, Universidad de Jaén, Centro de Estudios de Posgrado, 2016. Consultado en 2018 en http://tauja. ujaen.es/bitstream/10953.1/4346/1/TFM_Barranco_Lorente_Elisa\%20 Mar\%C3\%ADa.pdf

BazAnt, Jan, Antonio Haro y Tamariz y sus aventuras políticas: 1811-1869, México, El Colegio de México, 1985.

BonILla, Helia, "Santa Anna y los agentes de la voluptuosidad", en XXIX Coloquio Internacional de Historia del Arte, Miradas disidentes: género y sexo en la historia del arte, México, Universidad Nacional Autónoma de México, Instituto de Investigaciones Estéticas, 2007, p. 35-73.

, El Gallo Pitagórico (1842-1845): estampa, imprenta y política en torno a Santa Anna, tesis de doctorado en Historia del Arte, México, Universidad Nacional Autónoma de México, Instituto de Investigaciones Estéticas, 2013.

Bustamante, Carlos María de, Apuntes para la historia del gobierno del general don Antonio López de Santa Anna, edición facsimilar, pról. de Carmen Vázquez Mantecón, México, Instituto Cultural Helénico/Fondo de Cultura Económica, 1986.

, Diario histórico de México, CD-ROM, ed. de Josefina Z. Vázquez y Héctor Cuauhtémoc Hernández Silva, México, Centro de Investigaciones y Estudios Superiores en Antropología Social/El Colegio de México, 2001 y 2003 (CD 1: 1822-1834; y CD 2: 1835-1848).

Calderón de la Barca, Fanny, Life in Mexico: The Letter of Fanny Calderón de la Barca, with New Material from Author's Private Journals, Nueva York, Anchor Books, 1970.

, La vida en México durante una residencia de dos años en ese país, México, Porrúa, 1997.

CÁRdenas de la PeÑa, Enrique, Mil personajes en el México del siglo XIX: 1840-1870, México, Banco Mexicano Somex, 1979, v. III.

Costeloe, Michael, La república central en México, 1835-1846: "Hombres de bien" en la época de Santa Anna, México, Fondo de Cultura Económica, 2000. 
La primera república federal de México (1824-1835). Un estudio de los partidos políticos en el México independiente, 2a. reimp., México, Fondo de Cultura Económica, 1996.

Echánove Trujillo, Carlos A., La vida pasional e inquieta de don Crecencio Rejón, México, Sociedad Mexicana de Geografía y Estadística, 1941 (Boletín de la Sociedad de Geografía y Estadística, t. 53, n. 1 al 12).

Esparza Liberal, María José, "Los calendarios mexicanos del siglo Xix, una publicación popular", Boletín de Monumentos Históricos, Instituto Nacional de Antropología e Historia, México, v. 18, 2010, p. 32-146.

Fowler, Will, Mexico in the Age of Proposals, 1821-1853, Westport/Londres, Greenwood Press, 1998.

"La tercera y cuarta presidencia de Antonio López de Santa Anna (18411844)", en Will Fowler (coord.), Gobernantes mexicanos, México, Fondo de Cultura Económica, 2008, v. 1, p. 159-184.

Galí I BoAdella, Montserrat, "De Barcelona a L'Havana: Rafael de Rafael, una vocació hispanoamericanista”, Butlletí de la Societat Catalana d'Estudis Històrics, Filial del Institut d'Estudis Catalans, Barcelona, n. Ix, 1998, p. 105-127.

Cultura y política en el México conservador. La Lotería de la Academia Nacional de San Carlos (1843-1860), Puebla, Benemérita Universidad Autónoma de Puebla, Instituto de Ciencias Sociales y Humanidades "Alfonso Vélez Pliego"/Ediciones de Educación y Cultura, 2012.

GonZÁLEZ DE ZÁrate, Jesús María, “Imagen y poder, alegorías en emblemas”, en Rafael Zafra y José Javier Azanza (eds.), Emblemata Aurea: la emblemática en el arte y la literatura del Siglo de Oro, Madrid, Ediciones Akal, 2000.

HeRnÁNDEZ Del Ángel, Félix (comp.), Textos reunidos del licenciado Juan Bautista Morales (1788-1856). Documentos cartas literatura, Chalco, Edición del autor, 2014.

Textos reunidos del licenciado Juan Bautista Morales (1788-1856). Política y sociedad, Chalco, Edición del autor, 2016.

IGLESIAS, Ana Laura, "El mito de Faetón: sobre el exceso, lo fugaz y la conducción. Reflexiones sobre el relato y su apropiación”, en Modernidades, la historia en diálogo con otras disciplinas, 2006, consultado en 2016 en http://www.ffyh.unc. edu.ar/archivos/modernidades_a/IV/DEFINITIVOS/Articulo_Iglesias.htm\#_ ftn13.

Lanuza, Agustín, Historia del Colegio del Estado de Guanajuato, México, M. León-Sánchez imp., 1924.

Lombardo García, Irma, El siglo de Cumplido: la emergencia del periodismo mexicano de opinión, 1832-1857, México, Universidad Nacional Autónoma de México, Instituto de Investigaciones Bibliográficas, 2002. 
Malo, José Ramón, Diario de sucesos notables de José Ramón Malo (1832-1853), arreglados y anotados por el padre Mariano Cuevas, S. J., México, Patria, 1948.

Maza, Francisco de la, La mitología clásica en el arte colonial de México, México, Universidad Nacional Autónoma de México, Instituto de Investigaciones Estéticas, 1968 (Estudios y Fuentes del Arte en México, xxiv).

Morales, Juan Bautista, El Gallo Pitagórico, México, Imprenta de Ignacio Cumplido, 1845.

Moreno, Daniel (introd., selec. y notas), Manuel Crecencio Rejón: pensamiento político, México, Secretaría de Educación Pública, 1986 (Cien de México).

Noriega Elío, Cecilia, El Constituyente de 1842, México, Universidad Nacional Autónoma de México, Instituto de Investigaciones Históricas, 1986.

Pérez Salas Cantú, María Esther, "Los secretos de una empresa exitosa: la imprenta de Ignacio Cumplido”, en Laura Suárez de la Torre (coord.), Constructores de un cambio cultural: impresores-editores y libreros en la ciudad de México: 1830-1855, México, Instituto de Investigaciones Dr. José María Luis Mora, 2003, p. 101-181.

Prieto, Guillermo, Memorias de mis tiempos, México, Porrúa, 1985 (Colección "Sepan cuantos...", n. 381).

Olavarría y Ferrari, Enrique, México independiente, en Vicente Riva Palacio (coord.), et al., México a través de los siglos, 17a. ed., México, Cumbre, 1977, t. VII y viII.

Ovidio Nasón, Publio, Metamorfosis, vers. rítmica y notas de Rubén Bonifaz Nuño, México, Universidad Nacional Autónoma de México, Instituto de Investigaciones Filológicas, 1979 (Bibliotheca Scriptorvm Graecorvm et Romanorvm Mexicana).

Rodríguez Frausto, Jesús, "Juan Bautista Morales: abogado, político, periodista y escritor", Biografías, 32 al 36, 1960, s. n. p.

Santoni, Pedro, Mexican at Arms. Puro Federalists and the Politics of War, 18451848, Fort Worth, Texas Christian University Press, 1996.

Sigaut, Nelly, "El uso de la emblemática en un programa catedralicio", en Herón Pérez Martínez y Bárbara Skinfill Nogal (eds.), Esplendor y ocaso de la cultura simbólica, Zamora, El Colegio de Michoacán/Consejo Nacional para la Ciencia y la Tecnología, 2002.

VALDERRAMA Negrón, Ninel Hipatia, El fomento de la policía de ornato en la república de 1841-1844, tesis para obtener el grado de licenciada en Historia, México, Universidad Nacional Autónoma de México, 2010.

VÁzquez, Josefina Zoraida, Manuel Crecencio Rejón, México, Senado de la República, 1987. 
Zarco, Francisco, “El señor D. Juan Bautista Morales", en J. B. Morales, El Gallo Pitagórico: colección de artículos crítico-políticos y de costumbres, México, Imprenta de Ignacio Cumplido, 1857, p. I-XLVII.

El Monitor Republicano, 1849.

El Siglo Diez y Nueve, 1845.

El Ómnibus, 1856. 